Article

\title{
Life Cycle Assessment of a Biogas-Fed Solid Oxide Fuel Cell (SOFC) Integrated in a Wastewater Treatment Plant
}

\author{
Marta Gandiglio ${ }^{1, *(1)}$, Fabrizio De Sario ${ }^{1}$, Andrea Lanzini ${ }^{1}$, Silvia Bobba ${ }^{2}{ }^{(1)}$, \\ Massimo Santarelli ${ }^{1}$ and Gian Andrea Blengini ${ }^{2}$ \\ 1 DENERG-Department of Energy, Politecnico di Torino, Corso Duca Degli Abruzzi 24, 10129 Turin, Italy; \\ fabriziodesario@outlook.it (F.D.S.); andrea.lanzini@polito.it (A.L.); massimo.santarelli@polito.it (M.S.) \\ 2 DIATI-Department of Environment, Land and Infrastructures Engineering, Politecnico di Torino, Corso \\ Duca Degli Abruzzi 24, 10129 Turin, Italy; silvia.bobba@polito.it (S.B.); gianandrea.blengini@polito.it (G.A.B.) \\ * Correspondence: marta.gandiglio@polito.it; Tel.: +39-011-0904560
}

Received: 8 February 2019; Accepted: 19 April 2019; Published: 28 April 2019

\begin{abstract}
This work assesses the environmental impacts of an industrial-scale Solid Oxide Fuel Cell (SOFC) plant fed by sewage biogas locally available from a Waste Water Treatment Plant (WWTP). Three alternative scenarios for biogas exploitation have been investigated and real data from an existing integrated SOFC-WWTP have been retrieved: the first one (Scenario 1) is the current scenario, where biogas is exploited in a boiler for thermal-energy-only production, while the second one is related to the installation of an efficient SOFC-based cogeneration system (Scenario 2). A thermal energy conservation opportunity that foresees the use of a dynamic machine for sludge pre-thickening enhancement is also investigated as a third scenario (Scenario 3). The life cycle impact assessment (LCIA) has shown that producing a substantial share of electrical energy (around 25\%) via biogas-fed SOFC cogeneration modules can reduce the environmental burden associated to WWTP operations in five out of the seven impact categories that have been analyzed in this work. A further reduction of impacts, particularly concerning global warming potential and primary energy demand, is possible by the decrease of the thermal request of the digester, thus making the system independent from natural gas. In both Scenarios 2 and 3, primary energy and $\mathrm{CO}_{2}$ emissions embodied in the manufacture and maintenance of the cogeneration system are neutralized by operational savings in less than one year.
\end{abstract}

Keywords: life cycle assessment; biogas; fuel cell; solid oxide fuel cell; wastewater

\section{Introduction}

Fuel cells (FCs) are expected to play an important role in reducing environmental burdens associated with energy conversion technologies to achieve the current EU objectives [1]. Fuel cells are particularly interesting due to their high efficiency, modularity, excellent partial load performance, low pollution emissions and possible integration with other systems (e.g., steam or gas turbines) [2-5]. Solid oxide fuel cells (SOFCs) are suitable for distributed stationary power generation because of their fuel adaptability (they can employ a large variety of hydrocarbon fuels), the possibility of partial load operation and the possibility of cogeneration (heat recovery).

For sustainability evaluations, various policy documents underline the need of accurate information related to the environmental performances of products and service, especially in case of the introduction of innovative technologies on the market [6-8]. To assess the environmental sustainability of a product/service/new technology, a life cycle approach should be adopted to guide policymakers and consumer decisions and to introduce innovative sustainable technologies on the market [6-8]. 
Among the tools available to assess the environmental impacts of new technologies, Life Cycle Analysis (LCA) is a standardized methodology [9-11] widely used by the scientific community.

Large scale fuel cell systems have received growing interest in the scientific world and the market. Nonetheless, LCA of such systems is not straightforward and rarely available. Only a few studies deal with the LCA of real operating fuel cell plants.

Jing et al. [12] have developed a multi-optimized SOFC model evaluating, for a specific case study, environmental and economic benefits. When authors are talking about environmental analysis, they are mostly referring to emissions analysis. Life cycle analysis is indeed a comprehensive study able to evaluate the impact of a specified system over its entire lifetime. A recent study from Benveniste et al. [13] deals with the LCA of micro-tubular SOFC for auxiliary power units (APUs) fed by liquefied propane gas (converted into hydrogen in a dedicated catalytic reformer before being sent to the fuel cell): results show a reduction of $45 \%$ in terms of $\mathrm{CO}_{2}$ equivalent emissions and $88 \%$ in terms of Primary Energy consumption compared to conventional Diesel APU systems. Furthermore, the work points out that Global Warming Potential (GWP) and primary energy impacts could be reduced by reducing the energy consumed during the manufacturing phase and improving the system efficiency (operative phase).

The European Project FC-Hy Guide $[14,15]$ has extensively used life cycle assessments to better understand engineered solutions towards more environmentally sound fuel cell production and use. A guidance manual for LCA application to FC technologies and systems has been developed and contains essential information on how to build LCA of hydrogen-based and fuel cell technology, with details on the processes to be included, the approach, the steps and inputs/ outputs of the system [15]. FC-Hy Guide does not include a real case study application of the proposed method with SOFC, which is indeed developed in the presented work. The project has analyzed, in a published work [14], the LCA of a Molten Carbonate Fuel Cell (MCFC). The analysis shows a non-negligible impact, especially in GWP and abiotic depletion categories, of the fuel feeding the system (NG in this case) [14]. As far as the FC module manufacturing and operation is concerned, it instead affects acidification, eutrophication, photochemical oxidation, ozone layer depletion and human toxicity categories. Among the different components included in the MCFC system, the reformer is the most impacting in almost all categories, because it requires palladium and platinum catalyst, followed in impact by the power conditioning system. The use of a renewable gas feed (such as biogas) would help in reducing the fuel impact; furthermore, the reformer could also be avoided if green hydrogen from renewable sources would be chosen as fuel.

Despite the critical aspects shown by the previous work on MCFC, other studies on the LCA analysis of such systems show benefits compared to traditional technologies like microturbines [16-19]. Staffell et al. analyzed energy consumption, process-related emissions and carbon payback time of Combined Heat and Power (CHP) systems based on alkaline fuel cells or solid oxide fuel cells [20].

Other work available in the literature is related to polymer electrolyte fuel cells (PEMFCs) because of their interest for the automotive sector. Evangelisti et al. [21,22] compare an FC vehicle with an ICE-based vehicle and a battery electric vehicle. The production process showed a higher environmental impact for the FC vehicle compared to the production of the other two vehicle's power sources (and due to the hydrogen tank and the fuel cell stack). A potential reduction of $25 \%$ in the climate change impact category for the FCEV has also been detected when moving from the current scenario to an optimized one, with more enviromentaly friendly components (especially the hydrogen tank and the PEMFC stack). Over the entire life, ICE-based electric vehicles show the worst performance indeed because of fossil fuel use during use phase. One option to reduce environmental impact in terms of, for example, ADP of FC-based cars is the option of platinum recycling at the end of life, as analyzed by Duclos et al. [23]. Their work shows that more than half of the main impacts of the membrane-electrode-assembly can be avoided for four relevant impact categories if platinum is recovered at the end-of-life of the product. 
A similar state-of-the-art knowledge on LCA is also available — even if with a smaller number of contributions-for SOFCs: different works are available and deal with the various fields of applications of SOFC technology: APU [13], micro-CHP, large-size CHP, building sector [24]. Longo et al. [25] have analyzed LCA of PEMFC and SOFC in the book Hydrogen Economy, edited by Academic Press; here the authors provide a literature review of available LCA researches to point out the environmental impacts of the FCs. Mehmeti et al. [26] published a recent (2016) work reviewing the state of the art of LCA in SOFC systems. This is one of the most comprehensive works on the state of the art of SOFC systems.

Few works are available in the literature focused on the SOFC application in cogeneration mode in industrial plants. Tonini et al. [27] analyzed the biomass-based energy system in Denmark using LCA tool. The authors analyzed future scenarios (2030 and 2050) by introducing innovative energy system for transport fuels supply. SOFC, fed by biogas and syngas was used for electricity production in future scenarios. Thanks to the combination of the different technologies involved, the authors found a reduction ranging from 66 to $80 \%$ in GHG emissions.

Sadhukhan at al. [28] performed a comparison between biogas-fed SOFC, PEMFC, micro-GT and ICE in terms of environmental performance: in terms of avoided GWP, Acidification Potential (AP) and Photochemical Ozone Creation Potential (POCP), biogas based PEMFC microsystem is depicted as the most beneficial compared to the equivalent natural gas based systems. End-of-life management of SOFC materials is also another un-explored area, which could lead to interesting scenarios.

Life cycle assessment of biogas plants, without the use of innovative fuel cell systems, has been deeply studied in the literature. Recent studies focus on the comparison of different biogas exploitation paths in specific countries, like Malaysia-where a huge potential for biogas from palm oil biomass was found [29] - and Nigeria, where biogas from organic fraction of municipal solid waste was found [30]. Garfí et al. [31] evaluated the installation of small-size digesters for biogas production in Colombian farms: a potential environmental impact reduction up to $80 \%$ is associated with manure handling, fuel and fertilizer because of the biogas production. The same concept was demonstrated-through an environmental analysis-for Ethiopia by Gabisa et al. [32] and for Bangladesh by Ali et al. [33]. More recent and general reviews on LCA of agro-biogas are also available in literature [34,35]. Dedicated energy crops cultivation for biogas production has been evaluated by Torquati et al. [36]: crops production indeed plays a crucial role in the whole process LCA.

Most of the works related to the LCA of SOFC systems [37-39] are referring to the same databases when dealing with the SOFC manufacturing inventory. One of the central criticality of data collection on SOFC production is that there are not many companies worldwide, which are manufacturing SOFC systems at industrial scale. The novel aspects of the present work is the choice of recent and updated sources for data collection, both in terms of SOFC production and operation; in particular:

- For what concerns the SOFC manufacturing phase, a 2015 report from Ernest Orlando Lawrence Berkeley National Laboratory is used [40]. Thanks to the cooperation with the worldwide largest SOFC manufacturers, the report analyzed SOFC applications for use in CHP and power-sector only from 1 to $250 \mathrm{~kW}$-electric. The resulting total cost of ownership includes the direct manufacturing cost, operational costs, and life-cycle impact assessment of possible ancillary financial benefits during operation and at end-of-life. The report provides data on an industrial production of SOFC systems, which is difficult to find in literature and is available thanks to the laboratory cooperation with FC producers.

- For what concerns the operation phase and the SOFC management in a real industrial environmental, data have been retrieved from the DEMOSOFC (Demonstration of large SOFC system fed with biogas from WWTP) plant the first industrial-scale installation of a biogas-fed SOFC plant in Europe. The three SOFC modules, supplied by Convion [41], produce about $174 \mathrm{~kW}_{\mathrm{el}}$ and around $90 \mathrm{~kW}$-thermal. All the generated energy is self-consumed within the Waste Water Treatment Plant (WWTP) of Collegno (Torino, IT), where biogas is produced from sewage sludge. Two SOFC modules are currently running since October 2017. The use of real data represents a unique and significant added value for the LCA study. 
This work thus assesses the potential environmental impacts of a CHP plant that employs medium size SOFCs, fed by biogas produced by a WWTP facility, with a life cycle (cradle to gate) approach. The first section is related to the methodology presentation, the scenarios definition and the Life Cycle Inventory (LCI) (Sections 3-5), which discuss all the input data. Then, Section 6 shows and discuss the results. The primary goal of this study is the characterization of the energetic and environmental burdens of the three WWTP case studies through sustainability and life cycle impact indicators. The LCA developed in this work is comparative, so benefits or disadvantages are relative to the reference scenario (Scenario 1).

\section{Plant Layout and Scenarios Definition}

A WWTP is mainly divided into two sections (Figure 1): (1) a water line, in which wastewater undergoes to physical, biological and chemical treatments in order to meet the thresholds imposed by the existing standards; (2) a sludge line, where the organic matter separated during water purification is pumped towards the anaerobic digester. During the anaerobic digestion, microorganisms break down the organic substance contained in the sewage sludge and partially convert it into biogas. A WWTP needs electrical and thermal energy to sustain all these processes [42,43].

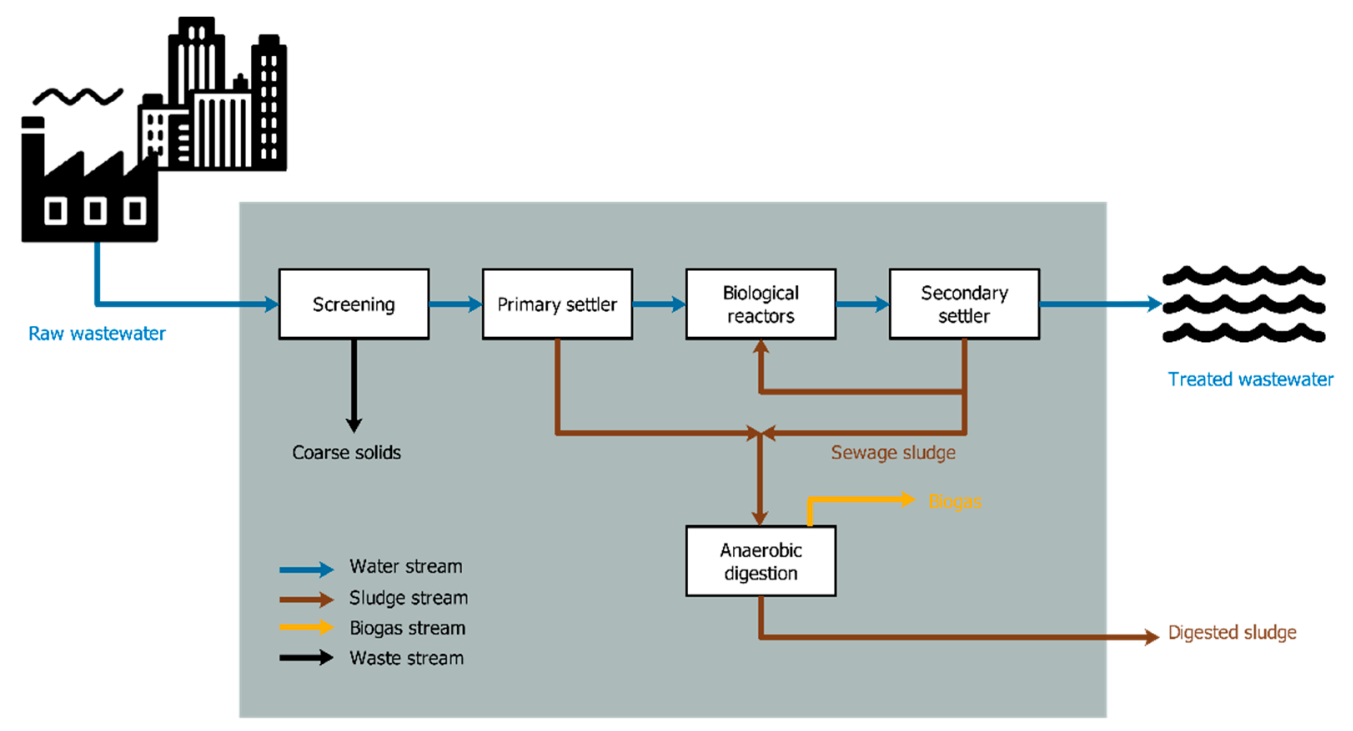

Figure 1. Simplified functional scheme of a WWTP.

Three different scenarios for the WWTP are presented:

- Scenario 1: the reference scenario in which all the electricity needed for operations is purchased from the grid and biogas is exploited in a boiler for thermal recovery or flared. No CHP system installed, and this represents the ante-DEMOSOFC scenario.

- Scenario 2: it foresees the installation of the SOFCs CHP system and biogas management improvements (since biogas is primarily sent to the CHP system and surplus gas, when available, is still used for thermal production in the existing boilers).

- Scenario 3: is similar to the second one but with an improvement in the anaerobic digestion line. A dynamic sludge pre-thickening machine is indeed employed to reduce the thermal demand of the anaerobic digester [44-48].

The WWTP analyzed in this work is sited in Collegno, a municipality within the metropolitan area of Turin, Italy [49]. A brief description of the integrated plant layout is useful to understand the primary energy and mass inputs/outputs of the system. The focus is on sludge and biogas lines since they are affected by the installation of the SOFC-CHP system within the wastewater treatment plant. 
In Scenario 1 (Reference) (Figure 2), raw and activated sludge produced during wastewater treatment are pre-thickened in separated tanks exploiting gravitational forces. Secondary sludge is treated with ozone to reduce the total amount of sludge volume to be processed. Although ozonization is not the best option for what concerns anaerobic digestion yield-biogas produced per capita is lower respect to other plants-it is an optimal process from the overall plant since it reduces the total amount of sub-products. Raw and activated sludge are both heated before entering the digester, which works in a mesophilic range of temperatures $\left(35-45^{\circ} \mathrm{C}\right)$. Part of the sludge and the produced biogas is continuously re-circulated in the tank to maintain high renewable-gas yield. The digested sludge is sent to a post-thickener, a press filter, to reduce the water content and make it available as fertilizer. The presence of a gas holder is fundamental to manage sludge and biogas production fluctuations, due to variable wastewater intake. The only use of biogas in this research is in boilers for producing the thermal energy needed for self-sustaining the anaerobic digestion process. Thermal demand of the anaerobic digester is equal to the sum of the energy required for sludge heating (up to set point temperature, $\sim 42{ }^{\circ} \mathrm{C}$ ) and that required to compensate losses through walls and pipes. Biogas in excess is flared. When biogas flow is not sufficient, the thermal demand is satisfied by natural gas taken from the network and feeding the boilers. The whole amount of electricity is purchased from the grid. Annual electrical and natural gas consumptions and average biogas yield and production rate are provided by the owners of the plant (SMAT, Società Metropolitana Acque Torino, [49]).

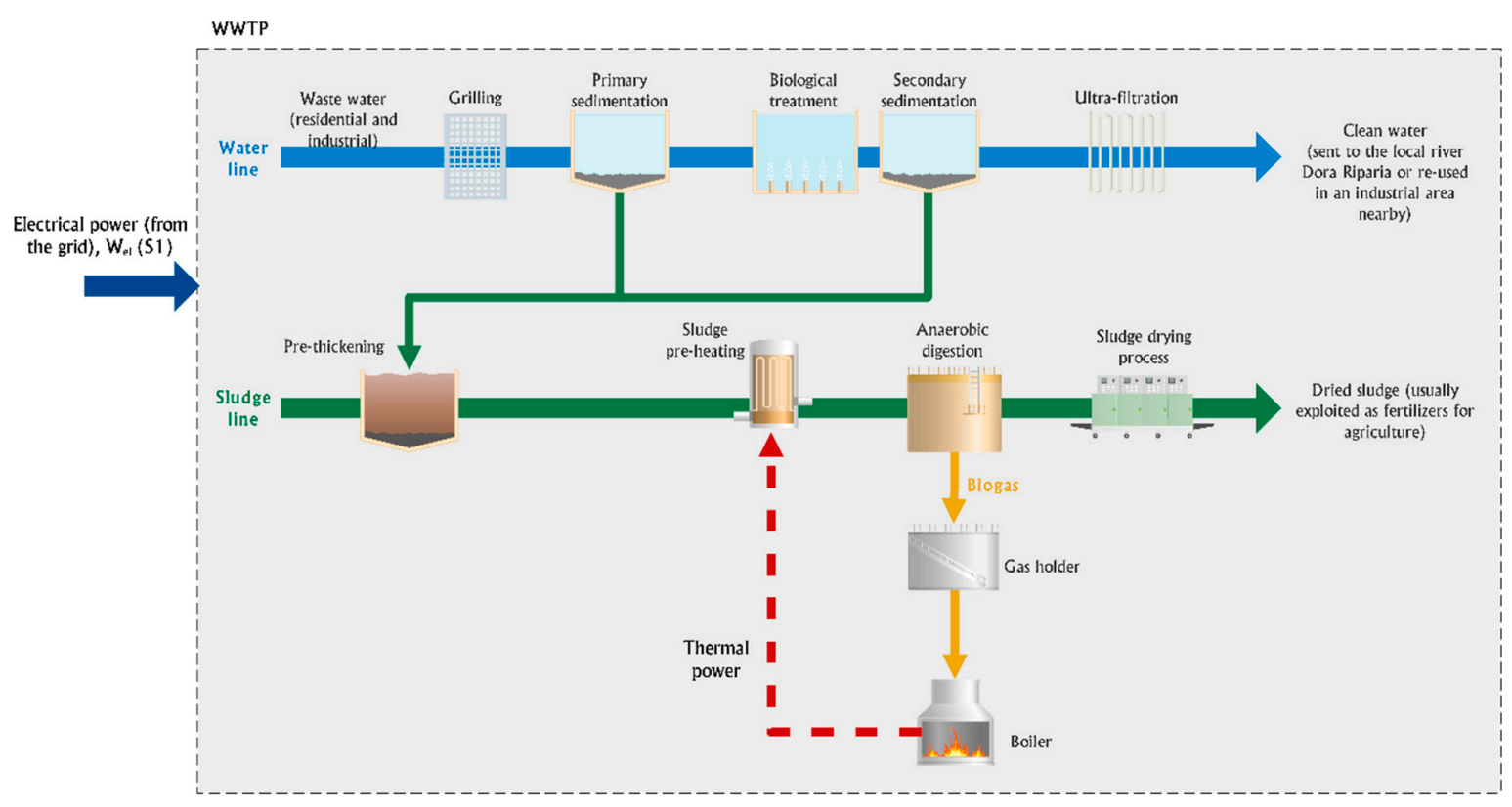

Figure 2. Scenario 1 (Reference scenario): biogas and sludge lines in the WWTP.

In Scenario 2, the installation of a not-conventional CHP unit improves the WWTP energetic self-sufficiency. Its very high electrical efficiency, and the operation in CHP mode are the motivation for the choice of the SOFC technology. Its adoption in the project is oriented towards its market introduction on an industrial scale using a demonstration of its energetic and environmental performance [50]. SOFCs generate electricity directly from the chemical energy contained in the biogas, with high efficiency and near-zero emissions of pollutants (e.g., $\mathrm{CO}, \mathrm{NO}_{\mathrm{x}}$, and hydrocarbons). The disadvantages are fuel cell sensitivity to biogas contaminants (in sewage biogas mainly sulfur and silicon compounds) and to thermal cycles (shutdown should be avoided). As shown in Figure 3, three main sections represent the change in infrastructure in the WWTP: 
- The biogas processing unit, where biogas is dehumidified, cleaned from harmful contaminants and compressed;

- $\quad$ SOFCs cogeneration modules (total power $174 \mathrm{~kW}_{\mathrm{el}}$ ), where electrical energy is produced and used for internal plant needs;

- Heat recovery section, where thermal power contained in exhaust gas exiting from SOFCs is recovered and transferred to the sludge entering the digester;

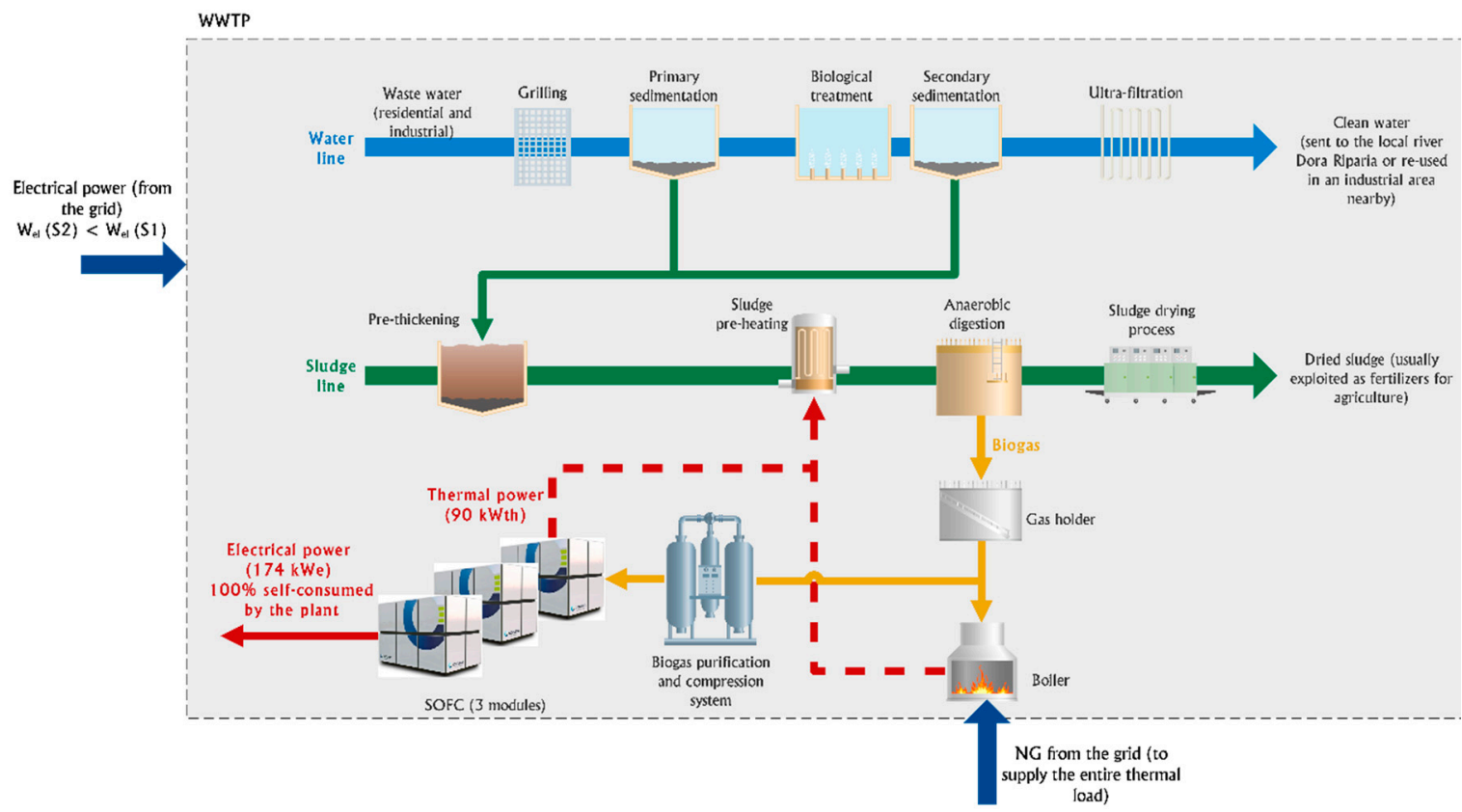

(a) Scenario 2

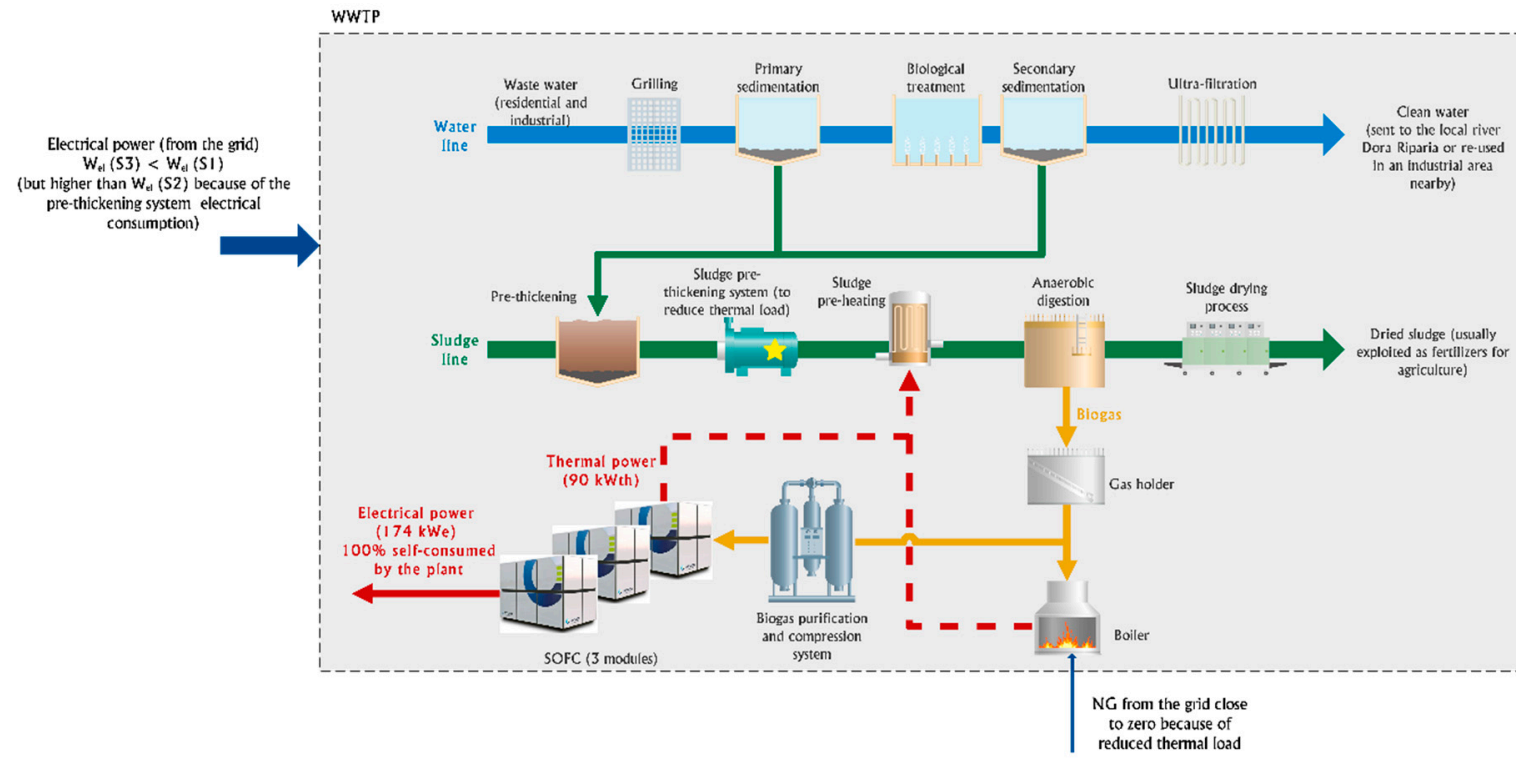

(b) Scenario 3

Figure 3. Biogas and sludge lines in the scenarios ((a) Scenario 2 and (b) Scenario 3) with SOFC based CHP system. 
Biogas handling is changed since now its primary goal is feeding the CHP modules while the surplus is sent to boilers to satisfy digester thermal demand.

Moreover, as in the reference case, biogas in excess in the gas holder is burned by the flare system. When the amount of biogas in the gas holder is not sufficient to cover digester thermal demand, natural gas is withdrawn from the grid. In this second scenario, the electrical consumption of the WWTP is higher, owing to absorption of the power of some components in the balance of plant (e.g., biogas compressor, chillers, and control system).

Scenario 3, in which the SOFC CHP unit is still present, foresees a reduction of the thermal demand for the anaerobic digestion process through an increase of the level of thickening of sludge (dry matter from $2.7 \%$ to $6.4 \%$ in weight) [51].

The use of a pre-thickening system for the inlet biomass to the digester is a strong WWTP optimization because it enables the plant to install high efficiency CHP systems while keeping self-sufficiency on the thermal power side. The sludge stream entering the diester has a very low solid content (usually around $2 \%$ ), and this generated a huge request of thermal power for pre-heating the flow from ambient to digester temperature. In case of an SOFC installation, thermal power production is reduced compared to the baseline (because of the electrical production) and is not anymore enough to cover the thermal load (and extra NG from the grid is required, thus increasing the fossil fuel consumption). When a pre-thickening system is installed, solid content is increased up to $5-8 \%$, and thermal power request is reduced. In this optimized scenario, the SOFC thermal production is able to almost fully cover the thermal demand of the digester, thus reducing/deleting the consumption of NG from the grid.

At the same time, the installation of a dynamic thickening machine is responsible for a slight increase in electrical consumptions of the WWTP.

Table 1 summarizes the resulting shares of electrical and thermal energy coverage and the biogas handling with the plant. Input data for the development of the energy balance are:

- SOFC electrical efficiency: $53.1 \%$ [41]

- SOFC thermal efficiency: $25.8 \%$ [41]

- Yearly equivalent capacity factor: $95 \%$ (assumption)

- Ordinary maintenance per year: 7.5 days (assumption)

- Digester thermal load (daily-based) definition as described in [52]

- Electrical load (monthly-based) from SMAT data. Average yearly consumption equal to 20.88 $\mathrm{kWh} / \mathrm{PE} / \mathrm{y}$, in line with the work developed by Panepinto et al. on a similar SMAT-owned WWTP [45]

- Boiler efficiency: $90 \%$

- Biogas average macro-composition: $60 \% \mathrm{CH}_{4}-40 \% \mathrm{CO}_{2}$

Table 1. Biogas management and energy sources in the three scenarios.

\begin{tabular}{|c|c|c|c|}
\hline Parameter/Scenario & Scenario 1 & Scenario 2 & Scenario 3 \\
\hline Electrical energy & Grid 100\% & $\begin{array}{l}\text { SOFC modules } 25.2 \% \\
\text { Grid } 74.8 \%\end{array}$ & $\begin{array}{c}\text { SOFC modules } 25.1 \% \\
\text { Grid } 74.9 \%\end{array}$ \\
\hline Thermal energy & $\begin{array}{l}\text { Biogas burned } 93 \% \\
\text { NG burned } 7 \%\end{array}$ & $\begin{array}{c}\text { SOFC modules } 23.5 \% \\
\text { Biogas burned } 31.4 \% \\
\text { NG burned } 45.1 \%\end{array}$ & $\begin{array}{l}\text { SOFC modules } 43 \% \\
\text { Biogas burned } 57 \% \\
\text { NG burned } 0 \%\end{array}$ \\
\hline Biogas handling $\left(^{*}\right)$ & $\begin{array}{c}\text { Boilers } 82.6 \% \\
\text { Flare } 16.6 \%\end{array}$ & $\begin{array}{c}\text { SOFC modules } 71.6 \% \\
\text { Boilers } 27.4 \% \\
\text { Flares } 0.2 \%\end{array}$ & $\begin{array}{c}\text { SOFC modules } 71.6 \% \\
\text { Boilers } 27.4 \% \\
\text { Flare } 0.2 \%\end{array}$ \\
\hline
\end{tabular}

$\left.{ }^{*}\right)$ Biogas losses from anaerobic digester are equal to $0.8 \%$ in all the scenarios. 
The onsite experience within the DEMOSOFC project is the source for the assumptions on the number of days for the ordinary maintenance and the yearly equivalent capacity factor. The only required yearly ordinary maintenance on the SOFC modules is the replacement of the air inlet filters and-on 1-2 years basis—-the reformer catalyst replacement.

As can be seen from Table 1, in scenario one all electricity is purchased from the grid and heat is supplied mainly by biogas (with an NG contribution only in winter season). In Scenario 2, around $25 \%$ of the electrical energy is self-produced thanks to the installation of the SOFC system. Thermal energy provided by NG is increased (from 7 to $45 \%$ ), because of the use of biogas in the CHP unit. This criticality is solved in the third scenario where electricity share is equal to the second one, but the thermal load is reduced (thanks to the installation of a sludge pre-thickening system) and consequently NG consumption is zero.

\section{Methodology}

\subsection{General Principles}

Life Cycle Thinking (LCT) is the basic concept referred to the need of assessing environmental and resource use burdens of a system adopting a holistic perspective, from raw material extraction to end of life, also to minimize the risk of environmental impact shifting [53].

Life Cycle Assessment (LCA) [9-11] can assist in identifying opportunities to improve the environmental performance of a system and informing decision makers using relevant impact indicators. In particular, the Life Cycle Impact Assessment (LCIA) phase includes the collection of indicator results for the different impact categories, which together represent the LCIA profile of the analyzed system. If the final user of LCA results would like to simplify category indicators further, optional steps as normalization, grouping, and weighting could be performed [54].

\subsection{System Boundaries}

The life cycle phases included in this work are manufacturing and maintenance of the SOFCs CHP system and operation of the WWTP in the three selected scenarios. End of life of products belonging to the analyzed system is not included since no exhaustive and satisfying information are available yet. The possibility of recycling and reusing some precious materials inside the studied system is clear and evident, so this can be cited as the first limitation of the here performed LCA, and further investigations are recommended.

The examined WWTP scenarios differ mainly in their infrastructures and in the way of handling biogas produced by the anaerobic digestion process (Figures 2 and 3). Therefore, the level of energy dependence from external resources (electricity and natural gas) used for sustaining wastewater processes changes among the analyzed scenarios (Table 1).

The comparative nature of this LCA is reflected in the definition of system boundaries of the three scenarios. All the processes shared among the compared scenarios are left outside of the boundaries. In Figures 4 and 5 the processes, material, and energy flow used to characterize the three scenarios are represented. The main foreground processes are boilers, digester, WWTP operations, and SOFCs CHP system manufacture, operation, and maintenance. 


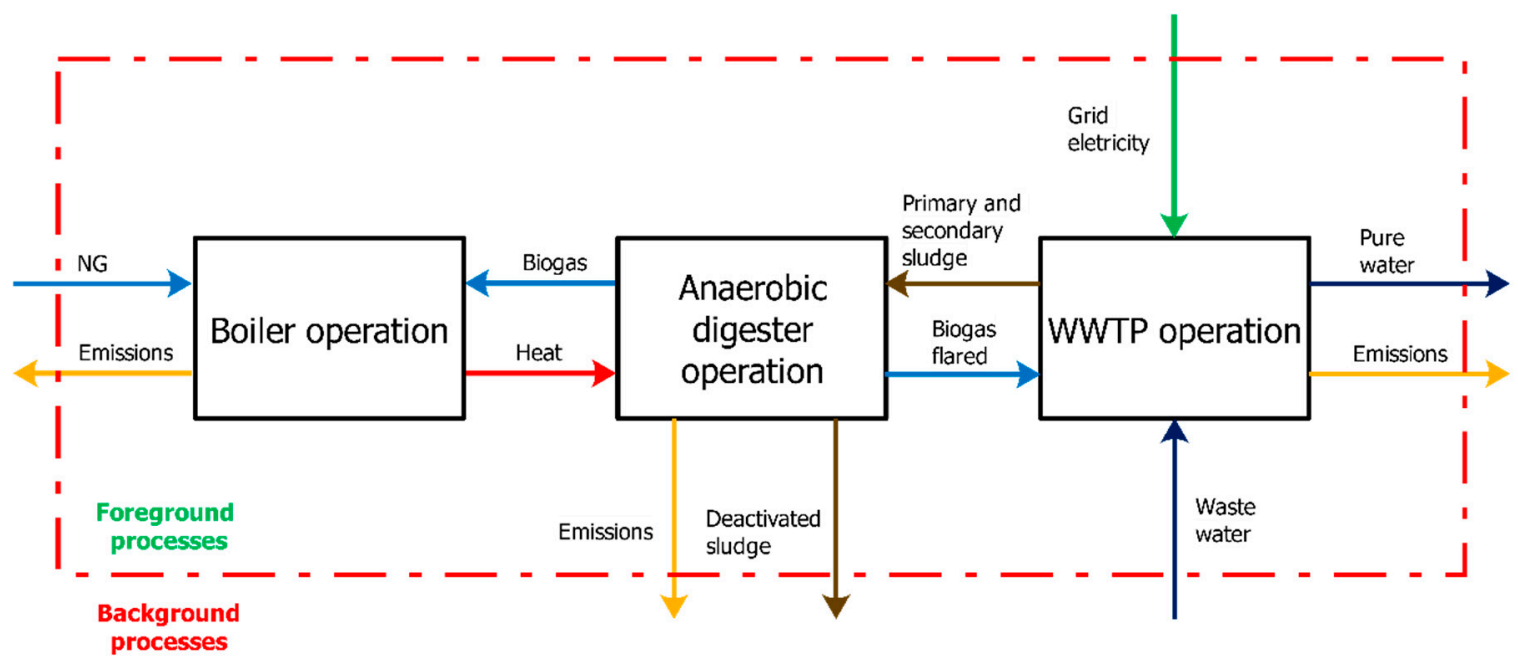

Figure 4. Boundaries of the reference WWTP (Scenario 1).

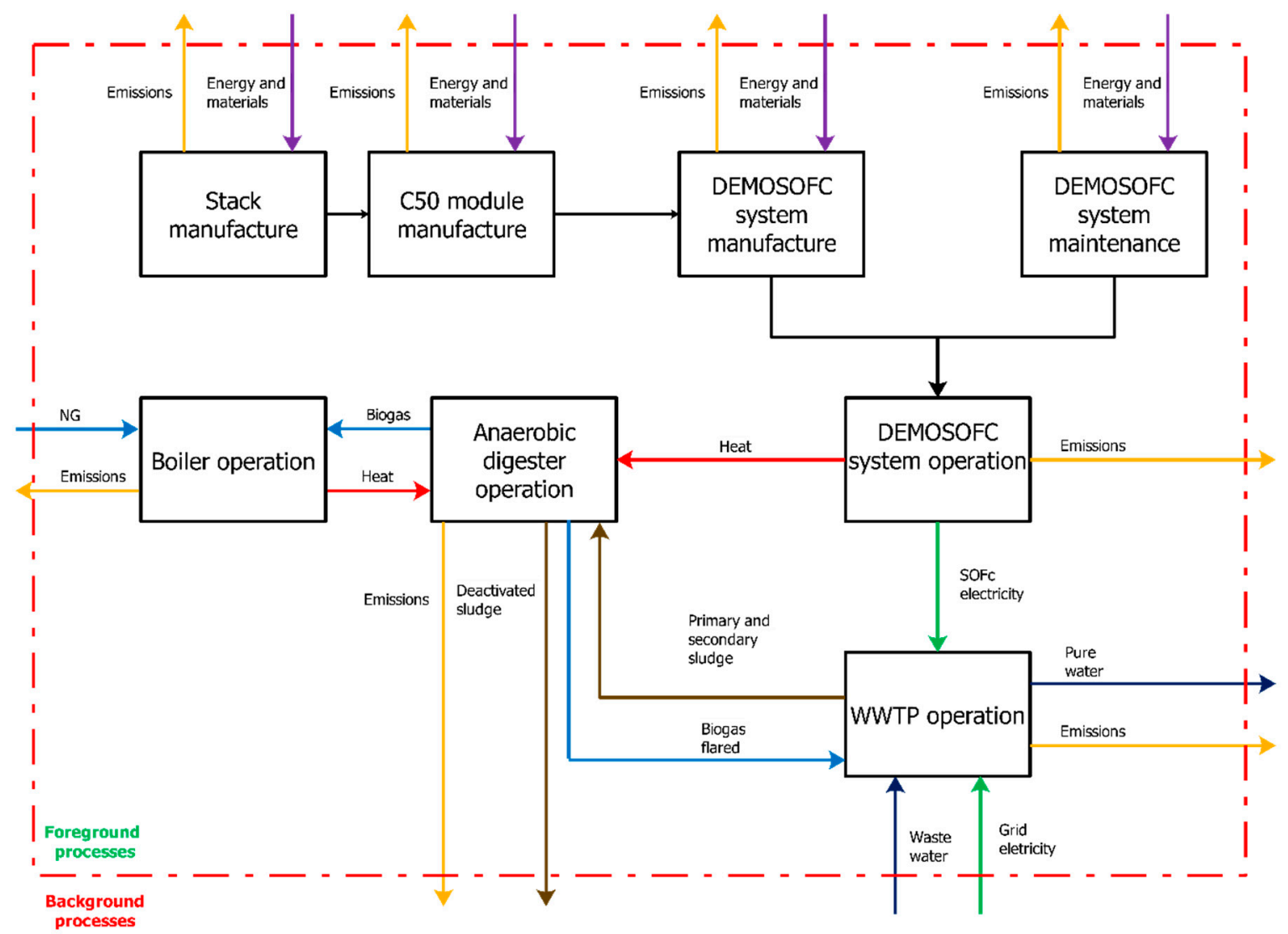

Figure 5. Boundaries of the WWTP with an SOFC-based cogeneration system (Scenarios 2 and 3).

\subsection{Functional Unit}

According to the LCA methodology, the functional unit allows the comparison of systems that are functionally equivalent. In this study, it is the wastewater treated by the plant in one year (around $14 \mathrm{Mm}^{3} / \mathrm{yr}$ for the SMAT Collegno WWTP [49]). The purification process requires high quantities of electricity, especially for the secondary biological treatment, and to guarantee sludge and water circulation within the plant [55]. Instead, thermal energy is needed to sustain the anaerobic digestion process that is optimized only in a specific range of temperature. What can be established, by fixing 
such functional unit and through a comparative LCA, is whether the SOFC based CHP system installed in the WWTP is sustainable from the environmental and energetic point of views.

\subsection{Impact Assessment Method and Related Indicators}

Accordingly to the guidance document for performing LCA on fuel cell and hydrogen technologies [15], CML (CML is a database that contains characterisation factors for LCIA developed at the Institute of Environmental Sciences of Leiden University) midpoint characterization factors (2010 version) has been selected. This method is in line with European environmental policy goals, widely used in practice, sufficiently robust and consistent with previous analyses performed by the authors [56].

To reduce as much as possible, the subjectivity associated with this work, midpoint impact categories have been chosen. Results expressed as damage to the area of protection (e.g., human health, biotic/abiotic environment, and resources) are more straightforward to understand but are more sensitive to specific hypothesis adopted in each characterization model. For the same reason, non-normalized and non-weighted results are preferred.

The impact categories and the corresponding indicator employed are:

- $\quad$ Global Warming Potential (GWP) in $\mathrm{kg} \mathrm{CO}_{2}$-eq

- Acidification Potential (AP) in $\mathrm{kg} \mathrm{SO}_{2}$-eq

- Abiotic Depletion Potential of elements (ADP) in kg Sb-eq

- Eutrophication Potential (EP) in $\mathrm{kg} \mathrm{PO}_{4}$-eq

- Ozone Depletion Potential (ODP) in kg CFC11-eq,

- $\quad$ Photochemical Ozone Creation Potential (POCP) in $\mathrm{kg} \mathrm{C}_{2} \mathrm{H}_{2}$-eq

- Primary Energy Demand from renewable and non-renewable resources (PED) in MWh-eq.

To further clarify the results, energy and carbon payback times are finally calculated. Energy payback time is determined as the ratio between the embodied energy through the system entire lifetime and the gross energy savings; carbon payback time is the ratio between the same embodied emissions and the total $\mathrm{CO}_{2}$ savings. The aim is showing in how many years of operation of the WWTP with SOFCs $\mathrm{CHP}$ system installed, the savings in primary energy and $\mathrm{CO}_{2}$ emissions, compared to the reference scenario, can balance the energy requirements and the carbon dioxide generated during manufacture and maintenance. For the implementation of the model, the LCA software GaBi $($ and the Ecoinvent 3.1 Database are used.

\section{Inventory}

For each scenario previously introduced, the unit processes included in the boundaries are analyzed, and the compilation of all the relevant input/output flows (concerning the functional unit) is performed. Figures 4 and 5 show that Scenario 1 (reference), in which biogas is exploited only in boilers for thermal power production, operational phases associated with the WWTP itself are part of the inventory. For Scenarios 2 and 3, in which a cogeneration system is installed in addition to the existing boilers, the analysis also includes the manufacturing and the operation and maintenance of the SOFC-based CHP system.

\subsection{SOFC Stack Manufacturing}

A solid oxide fuel cell is a device allowing the direct conversion of chemical into electrical energy, at high temperature. A single cell consists of three layers, a dense electrolyte between two porous electrodes (anode and cathode). Because of limitations in single cell voltage, the cells are connected in series to form a stack using interconnector plates, manifolds, flow fields, and sealant. This unit process is analyzed in detail since it is the core of the CHP system and innovative materials are continuously tested and employed to improve the overall efficiency. 
A detailed work developed at the Lawrence Berkeley National Laboratory has been the source of information on fuel cells manufacture [40]. The design and manufacturing steps of the SOFCs closely follow those of Fuel Cell Energy Inc., which has acquired Versa Power System. Table 2 shows the geometrical and functional characteristics of the selected SOFC stack.

Table 2. Characteristics of SOFCs manufactured by Versa Power; authors' own elaboration of data from $[40,57]$.

\begin{tabular}{ccc}
\hline \multicolumn{3}{c}{ Fuel Cell Energy (Versa Power) SOFC } \\
\hline Total plate area & 540 & $\mathrm{~cm}^{2}$ \\
\hline EEA dimensions & $18.15 \times 18.15$ & $\mathrm{~cm}$ \\
\hline Actively catalyzed area & 329 & $\mathrm{~cm}^{2}$ \\
\hline Single cell active area & 299 & $\mathrm{~cm}^{2}$ \\
\hline Gross cell inactive area & 45 & $\%$ \\
\hline Current density & 0.35 & $\mathrm{~A} / \mathrm{cm}^{2}$ \\
\hline Reference voltage & 0.8 & $\mathrm{~V}$ \\
\hline Power density & 0.28 & $\mathrm{~W} / \mathrm{cm}^{2}$ \\
\hline Cell power & 84 & $\mathrm{~W}$ \\
\hline Cells per stack & 130 & $\mathrm{units}$ \\
\hline Gross stack power & 11 & $\mathrm{~kW}$ \\
\hline Net stack power & 10 & $\mathrm{~kW}$ \\
\hline
\end{tabular}

It is essential, whenever a manufacturing process is analyzed, to fix the production volume to normalize material and energy flow respect to a reference unit, in this case, a single stack. From [40] it has been chosen a production volume of 50,000 stacks per year equal to 32,500,000 electrode-electrolyte assembly (EEA) cells per year. Another important aspect associated with a manufacturing analysis is the determination of line process parameters (e.g., line availability, performance, and yield), which are linked to the level of automation and the annual production volume of the site.

The part of the cells in which electrochemical reactions occur is the electrode-electrolyte assembly (EEA) which is planar, and anode supported. The anode is tape casted while the other layers are deposited on the support by screen printing machines (see Table 3 for details).

Table 3. Characteristics and manufacturing processes of EEA $[40,57]$.

\begin{tabular}{cccc}
\hline Component & Materials & Thickness $[\mu \mathrm{m}]$ & Process \\
\hline Anode & Ni/YSZ & 700 & Tape casting \\
\hline Anode-electrolyte interlayer & $50 \% \mathrm{NiO}+50 \% \mathrm{YSZ}$ & 10 & Screen printing \\
\hline Electrolyte & $\mathrm{YSZ}$ & 10 & Screen printing \\
\hline Cathode-electrolyte interlayer & $50 \% \mathrm{LSM}+50 \% \mathrm{YSZ}$ & 10 & Screen printing \\
\hline Cathode & $\mathrm{LSM}$ & 50 & Screen printing \\
\hline
\end{tabular}

With a single step co-firing all layers are sintered together in a kiln. The set of processes included in the EEA manufacturing analysis are slurry preparation, ball milling, de-airing and pumping, tape casting, screen printing, first quality control, co-firing, laser cutting and final quality control.

SOFC interconnectors are made of a stainless steel alloy (stainless steel 441 , composed of $17-24 \%$ of chromium) to maintain the right physical property at elevated operating temperatures. A manganese cobalt spinel oxide is physically vapor deposited and used as a protective layer to avoid chromium poisoning of the cathode. The processes involved in the interconnector manufacturing are stamping, 
cleaning and drying, PVD (Physical vapor deposition) of the coating and final inspection. SOFC frames are made of the same materials of interconnectors, and their manufacture foresees the use of analogous machines.

The seal is needed to prevent mixing and leaking of fuel and oxidant within/from the stack and to provide electrical isolation of cells and mechanical bonding of components. Planar SOFCs are usually jointed by means of glass seals. Cell to frame seal is applied for the cell to frame joining. Steps involved in the sealing process are ball milling of the glass paste and heating under a static load in a furnace. A semi-automatic stack assembly line is stacking up repeat units, and attaching current collectors or end plates to both ends of each stack. A final fully automated conditioning and the testing station is monitoring physical, chemical and electrochemical properties and performance. Table 4 shows the input data, where the reference unit is the manufacture of one stack of $10 \mathrm{~kW}$ nominal net power.

Table 4. Stack manufacture. Reference flow: $1 \mathrm{SOFC}$ stack, net power $10 \mathrm{~kW}_{\mathrm{el}}$ (data from [40,57]).

\begin{tabular}{|c|c|c|}
\hline Material/Energy Flows & Value & Unit \\
\hline \multicolumn{3}{|c|}{ Electrode-electrolyte assembly } \\
\hline $\mathrm{NiO}$ & 12.3 & $\mathrm{~kg}$ \\
\hline $8 Y S Z$ & 4.47 & $\mathrm{~kg}$ \\
\hline LSM & 1.07 & $\mathrm{~kg}$ \\
\hline Dibutyl phthalate (plasticizer) & 1.46 & $\mathrm{~kg}$ \\
\hline Polyvinyl Butyral (binder) & 1.46 & $\mathrm{~kg}$ \\
\hline Methocel A4M (binder) & 0.97 & $\mathrm{~kg}$ \\
\hline n-Butyl acetate $99.5 \%$ (solvent) & 4.39 & $\mathrm{~kg}$ \\
\hline 2-Butoxyethanol (solvent) & 0.55 & $\mathrm{~kg}$ \\
\hline Carbon black (pore former) & 0.95 & $\mathrm{~kg}$ \\
\hline Electricity consumption & 295 & $\mathrm{kWh}$ \\
\hline \multicolumn{3}{|c|}{ Interconnect and frame manufacturing process } \\
\hline 441 SS & 43.54 & $\mathrm{~kg}$ \\
\hline $\mathrm{MCO}$ & 0.73 & $\mathrm{~kg}$ \\
\hline Electricity consumption & 433 & $\mathrm{kWh}$ \\
\hline \multicolumn{3}{|c|}{ Glass seal production \& repeat unit assembly } \\
\hline Glass powder & 0.182 & $\mathrm{~kg}$ \\
\hline N-butyl acetate (solvent) & 0.050 & $\mathrm{~kg}$ \\
\hline Polyvinyl butyral (binder) & 0.018 & $\mathrm{~kg}$ \\
\hline Benzyl $n$-butyl phthalate (plasticizer) & 0.014 & $\mathrm{~kg}$ \\
\hline Electricity consumption & 234 & $\mathrm{kWh}$ \\
\hline \multicolumn{3}{|c|}{ Stack assembly and testing } \\
\hline $441 \mathrm{SS}$ & 29.68 & $\mathrm{~kg}$ \\
\hline Electricity consumption & 121 & $\mathrm{kWh}$ \\
\hline Emissions to air & Value & Unit \\
\hline \multicolumn{3}{|c|}{ Electrode-electrolyte assembly } \\
\hline Carbon dioxide & 4.32 & $\mathrm{~kg}$ \\
\hline $99.5 \%$ n-Butyl acetate (solvent) & 4.44 & $\mathrm{~kg}$ \\
\hline 2-Butoxyethanol (solvent) & 0.55 & $\mathrm{~kg}$ \\
\hline
\end{tabular}

Among the EEA manufacturing processes, the most energy intensive is co-firing which is responsible of around $73 \%$ of electrical demand. The total electrical consumption is $1083 \mathrm{kWh}$ per stack manufactured (so around $108 \mathrm{kWh} / \mathrm{kW}$ ), and a graph of contributions of processes is shown in 
Figure 6. Air emissions are related to the preparation of the slurry and the complete evaporation of solvents in the drying step. Carbon dioxide emissions are taken and scaled from [56].

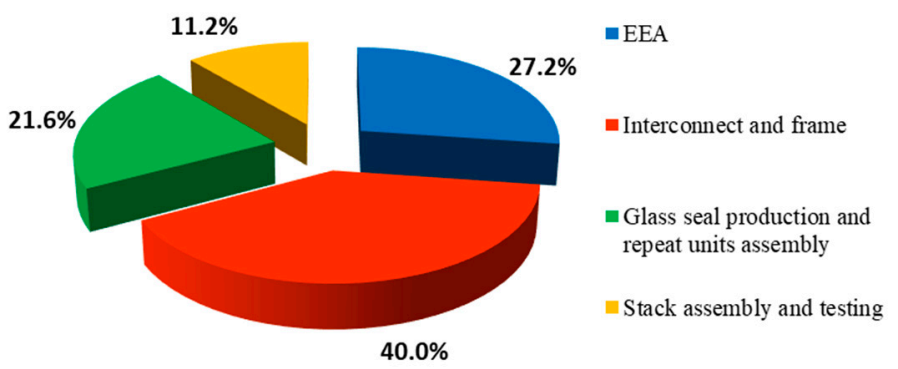

Figure 6. Energy consumptions associated with the stack manufacturing process.

A comparison with a merged inventory taken from literature [20] is performed to check the reliability of acquired data. This study is quite old and analyses a different type of fuel cells (electrolyte-supported EEA). Nevertheless, there is a reasonable agreement between Versa Power and literature data.

\subsection{CHP System Manufacturing}

The DEMOSOFC plant comprises of three C50 modules. The C50 is an SOFC power generator with a nominal power output of $58 \mathrm{~kW}$ (AC net) (Convion [41]). Thanks to its modular architecture, multiple units can be installed to achieve higher power outputs. Each module includes several SOFC stacks, a biogas pre-reformer, an afterburner, fuel, and air heat exchangers, blowers, air filters, start-up components (e.g., electrical resistance), control system, piping and valves, and casing. Since no specific information on materials and energy needed for manufacturing a C50 module are available from Convion, literature has been revised to find data on some of these components [40,56]. A general description of the balance of plant is useful to understand the compilation of inventory provided in Table 5.

Table 5. Manufacture of the SOFC based CHP system. Reference flow: 1 SOFC CHP system, net power $174 \mathrm{~kW}_{\mathrm{el}}$.

\begin{tabular}{lcc}
\hline \multicolumn{1}{c}{ Material/Energy Flows } & Value & Unit \\
\hline SOFC stack, $10 \mathrm{~kW}_{\mathrm{e}}$ & 18 & pieces \\
\hline Steam reforming catalyst & 53 & $\mathrm{~kg}$ \\
\hline WGS catalyst & 53 & $\mathrm{~kg}$ \\
\hline Stainless steel (mass contribution) & 16,000 & $\mathrm{~kg}$ \\
\hline Sheet rolling, stainless steel (process contribution) & 16,000 & $\mathrm{~kg}$ \\
\hline Reinforced steel (mass contribution) & 16,800 & $\mathrm{~kg}$ \\
\hline Sheet rolling, steel (process contribution) & 16,800 & $\mathrm{~kg}$ \\
\hline Activated carbon, siloxanes + VOCs & 1300 & $\mathrm{~kg}$ \\
\hline Activated carbon, $\mathrm{H}_{2} \mathrm{~S}$ & 650 & $\mathrm{~kg}$ \\
\hline Inverter (2.5 kW) & 70 & $\mathrm{pieces}$ \\
\hline Natural gas, burned in an industrial furnace & 23.6 & $\mathrm{MWh}_{\mathrm{th}}$ \\
\hline Electricity, IT consumption mix & 8.35 & $\mathrm{MWh}_{\mathrm{el}}$ \\
\hline
\end{tabular}

Biogas exiting the gas holder to feed the CHP units flows firstly through a recovery station, which comprises of a blower and a chiller, to have enough pressure to reach the treatment zone (positioned in another part of the WWTP) and avoid water condensation. In the biogas treatment 
section, filtration, compression, dehumidification, and post-filtration are performed to satisfy the strict purity requirements imposed by SOFCs (S level below $30 \mathrm{ppb}$, and total Si below $10 \mathrm{ppb}$ ). With the aim of improving the reliability and continuity of operation of the cleaning system, a lead and lag configuration is employed [50]. The clean-up reactors are adsorption vessels containing types of activated carbons specific for siloxanes and sulfur removal. Separated and dedicated feeding lines transport the purified biogas to the three SOFC modules.

Thermal recovery from C50 modules is performed using two interconnected loops. The use of a secondary water-glycol circuit is essential to avoid fouling of heat exchangers inside the CHP units due to the dirty stream of sludge involved. Therefore, heat released by hot exhaust is transferred to the water-glycol mixture and then to the sludge directed towards the anaerobic digester. As previously said, based on the amount of thermal energy available from CHP units, a certain amount of sludge can be pre-heated by the SOFC, while the remaining part is heated up through the conventional hot water loops of boilers, which are fed by extra-biogas available in the gas holder or by natural gas from the network.

The three C50 modules are connected to the grid. During start-up, the fuel cells absorb power from the grid, while during nominal operation power is exported. The connection of the SOFC modules with the external grid foresees medium voltage switchgear that is connected using transformers to the low voltage one. DC produced by SOFC must be converted through inverters in AC.

As it is easily understood, the analyzed balance of plant includes many components, and it is not possible to perform a detailed data collection for each of them. Rough but at the same time necessary approximations are performed when compiling the inventory. The path chosen is to scale, update and modify datasets of similar systems available in other studies $[56,58]$ according to the size of the analyzed plant.

Since C50 unit has a rated electrical power of $174 \mathrm{~kW}$ and in the WWTP three modules are installed, a total amount of 18 stacks (10 kW each, according to the initial assumptions) is considered when compiling the inventory. Inside the modules, a material flow that cannot be neglected during data collection is the catalysts present in steam reforming (SR) and water gas shift (WGS) reactors. These components convert the methane contained in biogas to syngas before feeding the anode of SOFCs. The SR reaction is strongly endothermic and creates more gas volume as the hydrocarbon is converted. This means that high temperatures and low pressures favor it. Instead, WGS reaction is slightly exothermic, so it is supported by low temperatures. Both reactions are catalyzed to improve methane conversion and decrease the risk of carbon formation. Several parameters influence the choice of the catalyst: primarily activity and cost but also the potential for carbon formation, heat transfer, strength and packing properties, pressure drop during operation [59]. Modern catalysts are for the most part made of supports onto which the active metal is impregnated. In this study, it has been supposed that the reactors use catalysts composed of $63 \%$ of alumina, $20 \%$ of nickel and the rest of silicon for steam reforming and iron for water gas shift. Information about the amount of catalysts employed is taken from $[60,61]$, by scaling available literature data based on biogas flow to CHP modules. The same amount of catalyst in SR and WGS reactors has been assumed.

All the other components of a C50 module are assumed made of stainless steel since they operate at high temperatures. A single module weighs six tons, and the amount of stainless steel has been determined by subtracting the mass of stacks and catalysts.

Concerning the fuel processing unit, the clean-up filtering media have been modeled. Activated carbons are employed as adsorbent materials for sulfur, siloxanes and VOC (Volatile organic compounds) removal. Activated carbons (AC) can be manufactured from a variety of raw materials that have a high percentage of carbon content and low impurities. Activated carbons are characterized by a very high internal surface area. In the four tanks dedicated to siloxanes and VOCs removal, non-impregnated steam activated carbons produced from coal are used. The amount of filtering media needed per bed has been calculated scaling data from [62] as a function of biogas flow rate. Some parameters 
affect the quantity of filtering media used, such as operating temperature and pressure and level of purification pursued.

The other mechanical components of the biogas processing system and the heat recovery section are considered in terms of the equivalent amount of reinforced steel. For the SOFCs CHP system, a specific weight of $200 \mathrm{~kg}$ of steel per installed electric $\mathrm{kW}$ is taken from [58]. Making a difference with the weight of C50 modules, the BoP (Balance of plant) result composed of around 16.8 tons of reinforced steel. The electric system is modeled with the number of inverters of $2.5 \mathrm{~kW}$ needed to reach total power $(174 \mathrm{~kW})$. The electrical and thermal energy required for CHP system production and assembly is taken from [58] and scaled based on the power plant size. As said, these rough simplifications are necessaries since specific data from manufacturers, or suitable datasets in databases for some components of the BoP, are not available.

\subsection{CHP System Maintenance}

In this life cycle phase, all the necessary replacements of parts and consumables are considered. It is assumed a six years lifetime for the SOFC. Concerning the activated carbons, each adsorption vessel in lead position will reach saturation after six months of continuous operation, so that two replacements per year are required. The catalysts of SR and WGS reactors are entirely replaced every four years. Other maintenance requirements (e.g., malfunctioning parts, occasional damages) are modeled as substitution of steel corresponding to $1 \%$ of the total mass in the system. Primary data are reported in Table 6.

Table 6. Maintenance of the SOFC based CHP system. Reference flow: maintenance interventions in one year.

\begin{tabular}{ccc}
\hline Material/Energy Flows & Value & Unit \\
\hline Stacks' replacement $^{\prime}$ & 3 & pieces \\
\hline Reinforced steel & 262 & $\mathrm{~kg}$ \\
\hline Stainless steel & 66 & $\mathrm{~kg}$ \\
\hline Steam reforming catalyst & 13 & $\mathrm{~kg}$ \\
\hline WGS catalyst & 13 & $\mathrm{~kg}$ \\
\hline Activated carbon, siloxanes + VOCs & 1300 & $\mathrm{~kg}$ \\
\hline Activated carbon, $\mathrm{H}_{2} \mathrm{~S}$ & 650 & $\mathrm{~kg}$ \\
\hline
\end{tabular}

\subsection{CHP System Operation}

Reference flows are thermal and electrical energy produced by SOFC modules in one year. Since the CHP system was not operational when the analysis was performed, the simulation of plant performance is achieved through a tailored energy planner tool [63-65]. The installation in the WWTP of an SOFC CHP system implies the determination of smart and efficient management of biogas stored in the gas holder. For the scope of this work, it is enough to say that the primary aim is to avoid fuel shortages and to minimize SOFC shutdowns during the year. This goal is reached using a regulation of the SOFC power output according to the monitoring of the gas holder level. In Table 7 the most important operational parameters, obtained from the simulation, associated with the three SOFC modules, are reported. In the calculations, a constant percentage of methane of $60 \%$ is considered in the biogas and a corresponding lower heating value of $21.5 \mathrm{MJ} / \mathrm{Nm}^{3}$.

The multi-functionality issue associated with the production of heat and electricity by the CHP units is solved through the allocation based on exergetic contents of these streams. In Table 8 the inventory associated with CHP system operations is shown. The amount of system necessary for one year of operation is calculated as the inverse of plant lifetime, assumed of 20 years. 
Table 7. SOFC modules, outputs of the energy planner tool [63].

\begin{tabular}{ccc}
\hline \multicolumn{3}{c}{ SOFC Modules } \\
\hline Nominal electrical power & 174 & $\mathrm{~kW}_{\mathrm{e}}$ \\
\hline Nominal biogas flow rate & 55 & $\mathrm{Nm}^{3} / \mathrm{h}$ \\
\hline Equivalent capacity factor & 95 & $\%$ \\
\hline Number of shutdowns & 0 & $/$ \\
\hline Avg. biogas flow rate & 52.3 & $\mathrm{Nm}^{3} / \mathrm{h}$ \\
\hline Effective electrical power & 166.2 & $\mathrm{~kW}_{\mathrm{e}}$ \\
\hline Thermal power & 81.1 & $\mathrm{~kW}_{\text {th }}$ \\
\hline Avg. electrical efficiency & 53.1 & $\%$ \\
\hline Avg. thermal efficiency & 25.8 & $\%$ \\
\hline Annual operating hours & 8581 & $\mathrm{~h}$ \\
\hline
\end{tabular}

Table 8. The operational phase of the SOFC based CHP system. Reference flows, 1427 MWh electricity and 693 MWh heat (1 year of operation).

\begin{tabular}{|c|c|c|}
\hline Material/Energy Flows & Value & Unit \\
\hline Biogas to SOFC & 449,084 & $\mathrm{Nm}^{3}$ \\
\hline DEMOSOFC system & 0.05 & pieces \\
\hline DEMOSOFC maintenance & 1 & pieces \\
\hline \multicolumn{3}{|c|}{ Emissions to Air } \\
\hline Carbon dioxide, biogenic & 880.8 & ton \\
\hline
\end{tabular}

\subsection{Boilers Operation}

As already said, thermal energy is requested to maintain the anaerobic digester in an optimal range of temperatures, to maximize biogas yield of the process. The exhaust gas analysis, and so the emissions associated with combustion, have been provided directly from maintainers of the plant. The amount of biogas and natural gas (NG) burned in boilers changes among different scenarios, so separated inventories have been produced in Table 9. The common reference flow is the amount of heat delivered in one year of operation.

Table 9. The operational phase of the boilers (primary data from data collection at the WWTP site).

\begin{tabular}{ccc}
\hline \multicolumn{3}{c}{ Scenario 1, Reference Flow: } \\
\hline Mo06 MWh Heat & \\
\hline Material/energy flows & Value & Unit \\
\hline Natural gas, IT mix & 25,610 & $\mathrm{Nm}^{3}$ \\
\hline Biogas to boilers & 518,408 & $\mathrm{Nm}^{3}$ \\
\hline \multicolumn{2}{c}{ Emissions to Air } & \\
\hline Carbon dioxide, biogenic & 1020.2 & ton \\
\hline Carbon dioxide, fossil & 50.5 & ton \\
\hline Carbon monoxide, biogenic & 186.9 & $\mathrm{~kg}$ \\
\hline Carbon, monoxide, fossil & 15.4 & $\mathrm{~kg}$ \\
\hline Nitrogen oxide & 181.7 & $\mathrm{~kg}$ \\
\hline Nitrogen dioxide & 15.1 & $\mathrm{~kg}$ \\
\hline
\end{tabular}


Table 9. Cont.

\begin{tabular}{|c|c|c|}
\hline \multicolumn{3}{|c|}{ Scenario 2, Reference Flow: 2256.3 MWh Heat } \\
\hline Material/energy flows & Value & Unit \\
\hline Natural gas, IT mix & 155,317 & $\mathrm{Nm}^{3}$ \\
\hline Biogas to boilers & 172,241 & $\mathrm{Nm}^{3}$ \\
\hline \multicolumn{3}{|c|}{ Emissions to Air } \\
\hline Carbon dioxide, biogenic & 338.9 & ton \\
\hline Carbon dioxide, fossil & 306.0 & ton \\
\hline Carbon monoxide, biogenic & 62.1 & $\mathrm{~kg}$ \\
\hline Carbon, monoxide, fossil & 93.3 & $\mathrm{~kg}$ \\
\hline Nitrogen oxide & 139.6 & $\mathrm{~kg}$ \\
\hline Nitrogen dioxide & 11.6 & $\mathrm{~kg}$ \\
\hline \multicolumn{3}{|c|}{ Scenario 3, Reference Flow: 925.4 MWh Heat } \\
\hline Material/energy flows & Value & Unit \\
\hline Natural gas, IT mix & 0 & $\mathrm{Nm}^{3}$ \\
\hline Biogas to boilers & 172,241 & $\mathrm{Nm}^{3}$ \\
\hline \multicolumn{3}{|c|}{ Emissions to Air } \\
\hline Carbon dioxide, biogenic & 338.9 & ton \\
\hline Carbon dioxide, fossil & 1 & 1 \\
\hline Carbon monoxide, biogenic & 62.1 & $\mathrm{~kg}$ \\
\hline Carbon, monoxide, fossil & 1 & 1 \\
\hline Nitrogen oxide & 55.8 & $\mathrm{~kg}$ \\
\hline Nitrogen dioxide & 4.6 & $\mathrm{~kg}$ \\
\hline
\end{tabular}

\subsection{Anaerobic Digester Operation}

The digestion process requires thermal energy, but also electricity for sludge mixing and recirculation. The processes to which wastewater is subjected to obtain raw sludge, as well as the subsequent treatment of the digested matter, are outside of the boundaries of the study since they are common phases of different scenarios. Carbon dioxide and methane emissions are due to leakage of pipes during the process and are assumed to be $0.75 \%$ of produced biogas according to [66]. The reference flow is the annually produced biogas; collected data are reported in Table 10.

Table 10. The operational phase of the anaerobic digester (primary data from data collection at the WWTP site)

\begin{tabular}{|c|c|c|}
\hline \multicolumn{3}{|c|}{ Scenario 1, Reference Flow: $627041 \mathrm{Nm}^{3}$ Biogas } \\
\hline Material/energy flows & Value & Unit \\
\hline Heat, from boiler operation & 3006 & MWh \\
\hline Electricity, IT mix, from the grid & 158 & MWh \\
\hline Lubricating oil, at the plant & 178.6 & $\mathrm{~kg}$ \\
\hline \multicolumn{3}{|c|}{ Emissions to Air } \\
\hline Carbon dioxide, biogenic & 3715 & $\mathrm{~kg}$ \\
\hline Methane, biogenic & 2022 & $\mathrm{~kg}$ \\
\hline
\end{tabular}


Table 10. Cont.

\begin{tabular}{|c|c|c|}
\hline \multicolumn{3}{|c|}{ Scenario 2, Reference Flow: $627041 \mathrm{Nm}^{3}$ Biogas } \\
\hline Material/energy flows & Value & Unit \\
\hline Heat from boilers operation & 2256.3 & MWh \\
\hline Heat from SOFC & 693.1 & MWh \\
\hline Electricity, IT mix, from the grid & 158 & MWh \\
\hline Lubricating oil, at the plant & 178.6 & $\mathrm{~kg}$ \\
\hline \multicolumn{3}{|c|}{ Emissions to Air } \\
\hline Carbon dioxide, biogenic & 3715 & $\mathrm{~kg}$ \\
\hline Methane, biogenic & 2022 & $\mathrm{~kg}$ \\
\hline \multicolumn{3}{|c|}{ Scenario 3, Reference Flow: $627041 \mathrm{Nm}^{3}$ Biogas } \\
\hline Material/energy flows & Value & Unit \\
\hline Heat from boilers operation & 925.4 & $\mathrm{MWh}_{\mathrm{t}}$ \\
\hline Heat from SOFC & 693.1 & $\mathrm{MWh}_{\mathrm{t}}$ \\
\hline Electricity, IT mix, from the grid & 171 & $\mathrm{MWh}_{\mathrm{e}}$ \\
\hline Lubricating oil, at the plant & 178.6 & $\mathrm{~kg}$ \\
\hline \multicolumn{3}{|c|}{ Emissions to Air } \\
\hline Carbon dioxide, biogenic & 3715 & $\mathrm{~kg}$ \\
\hline Methane, biogenic & 2022 & $\mathrm{~kg}$ \\
\hline
\end{tabular}

\subsection{WWTP Operation}

This unit process includes electrical consumptions associated to plant operations, and emissions associated with biogas in excess, which is flared. It is assumed that the whole amount of methane burned is oxidized and converted in carbon dioxide (and water) since no specific information on emissions is available. The functional unit is the amount of wastewater treated by the WWTP in one year; collected data are reported in Table 11.

Table 11. The operational phase of the WWTP (primary data from data collection at the WWTP site).

\begin{tabular}{|c|c|c|}
\hline \multicolumn{3}{|c|}{ Scenario 1, Reference Flow: 13,958,807 $\mathrm{m}^{3}$ Treated Wastewater } \\
\hline Material/energy flows & Value & Unit \\
\hline Electricity, IT mix, from the grid & 5479.4 & MWh \\
\hline Biogas flared & 103,930 & $\mathrm{Nm}^{3}$ \\
\hline \multicolumn{3}{|c|}{ Emissions to Air } \\
\hline Carbon dioxide, biogenic & 204.1 & ton \\
\hline \multicolumn{3}{|c|}{ Scenario 2, Reference Flow: $13,958,807$ Idem m$^{3}$ Treated Wastewate } \\
\hline Material/energy flows & Value & Unit \\
\hline Electricity, IT mix, from the grid & 4078 & MWh \\
\hline Electricity from SOFC & 1427 & MWh \\
\hline Biogas flared & 1008 & $\mathrm{Nm}^{3}$ \\
\hline \multicolumn{3}{|c|}{ Emissions to Air } \\
\hline Carbon dioxide, biogenic & 1.98 & ton \\
\hline
\end{tabular}


Table 11. Cont.

\begin{tabular}{|c|c|c|}
\hline \multicolumn{3}{|c|}{ Scenario 3, Reference Flow: $13,958,807$ Idem $\mathrm{m}^{3}$ Treated Wastewater } \\
\hline Material/energy flows & Value & Unit \\
\hline Electricity, IT mix, from the grid & 4078 & MWh \\
\hline Electricity from SOFC & 1427 & MWh \\
\hline Biogas flared & 1008 & $\mathrm{Nm}^{3}$ \\
\hline \multicolumn{3}{|c|}{ Emissions to Air } \\
\hline Carbon dioxide, biogenic & 1.98 & ton \\
\hline
\end{tabular}

\section{Results and Discussion}

The first step necessary for the interpretation of the results is the analysis of the LCIA profiles of the investigated scenarios, to understand which life cycle phases, unit processes and flows result in the highest impacts why.

\subsection{Energetic Flows and LCIA Profiles}

Energy flow referred to the three analyzed scenarios are provided in Appendix A. In the reference scenario, biogas handle has yet noted, is not optimized since a relevant amount is flared without producing useful effects. Looking at the LCIA profile in Figure 7a, it is clear that the process called WWTP operation gives the highest contribution in all the impact categories. This is due to the significant amount of electricity needed by the plant for its operations.

Italian consumption mixes of electricity and natural gas of 2009 (last update available in the software) have been used for this evaluation. The electricity flow includes production, transport, and mix of energy carriers, conversion processes in power plants and final transmission. In the GWP category, the operation of boilers gives an essential contribution of around $26 \%$, which is mainly attributable to emissions of carbon dioxide during the combustion process. The negative share (avoided impact) of boilers in the POCP category is determined by the negative contribution of $\mathrm{NO}$ emissions which play a predominant role.

In the second scenario, the LCA model shows how an improvement in biogas management with a reduction in the amount of primary resource flared (from 16.6 to $0.2 \%$ ). Furthermore, a predominant amount of biogas (around 72\%) is used in the CHP system to produce first electrical energy and then heat by means of a thermal recovery from the exhaust gases. As can be seen in Figure 7b, even in this case the process called WWTP operation has a significant role in all the impact categories except the ADP. Nevertheless, all the shares associated with this process are reduced in comparison to the first scenario, because the SOFC CHP system produces a portion of the electrical energy. The ADP of elements is prevalently linked to the change of infrastructure in the WWTP and so to the manufacture and maintenance of the cogeneration system. Steel and copper are the materials used in more significant amounts which have a predominant influence on this category. GWP and ODP are also heavily affected by the installation and operations of the CHP units. In the first, the results are linked to different biogas handling, which is mainly used for electricity production in SOFC modules where methane is oxidized to carbon dioxide through SR and WGS reactions. In the second, the manufacturing and maintenance phases give almost $37 \%$ of contribution, and main sources of ozone-depleting substances are the processes of production of steel, copper, and materials of the EEA (such as nickel oxide, LSM and YSZ). In the PED the contribution of the operational phase of boilers increases up to $14 \%$ since, in this scenario, the thermal energy generated from biogas decreases and consequently a higher consumption of NG is necessary to satisfy the digester demand.

In the third scenario, the reduction of thermal demand for the digestion process is a consequence of the increase in the level of pre-thickening of sludge up to $6.4 \% \mathrm{wt}$., thanks to the installation of the dynamic machine. As yet said this is the level of dry organic matter inside the sludge which allows the 
WWTP to be independent of natural gas. The slight increase in electricity consumption in the process called digester operation is owed to absorptions of the dynamic machine.

In Figure 7c, the LCIA profile of this scenario is reported. Main differences respect to the second scenario arises in GWP and PED concerning the operational phase of boilers. The primary energy demand associated with this process is null since no external resources are employed and the decrease of GWP is attributable to lower production of heat and related emissions.

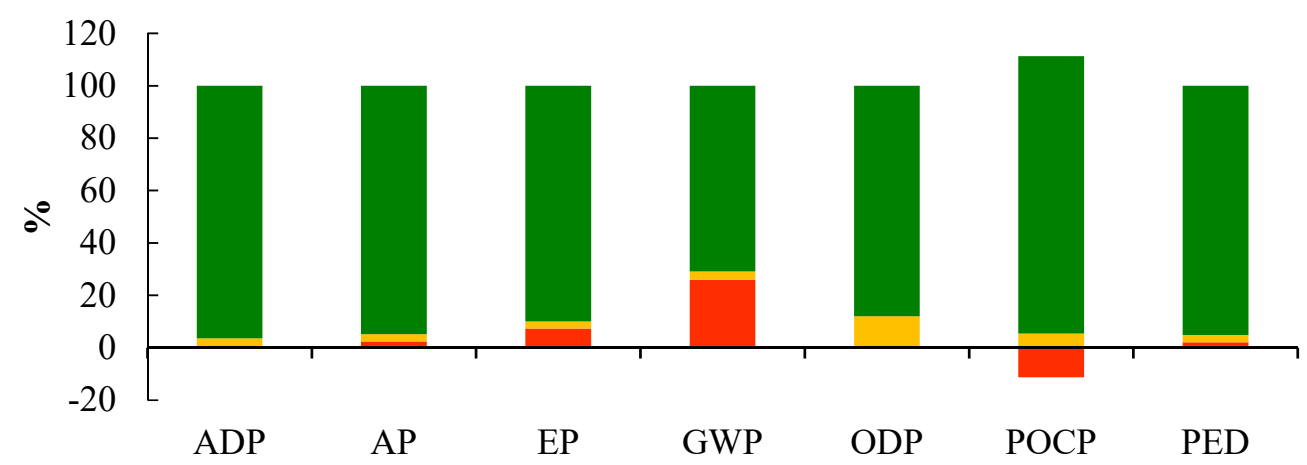

(a) Scenario 1 (reference)

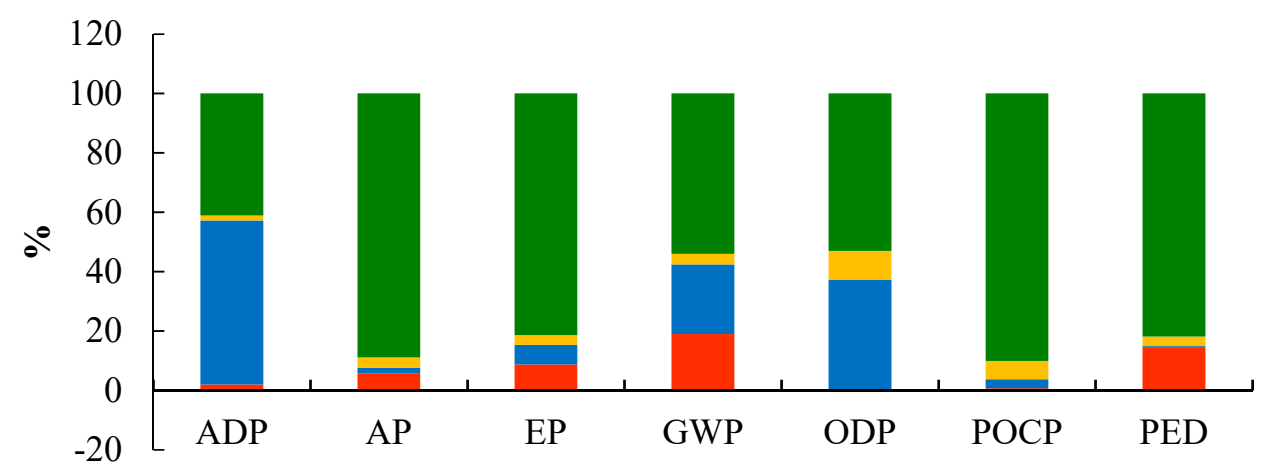

(b) Scenario 2

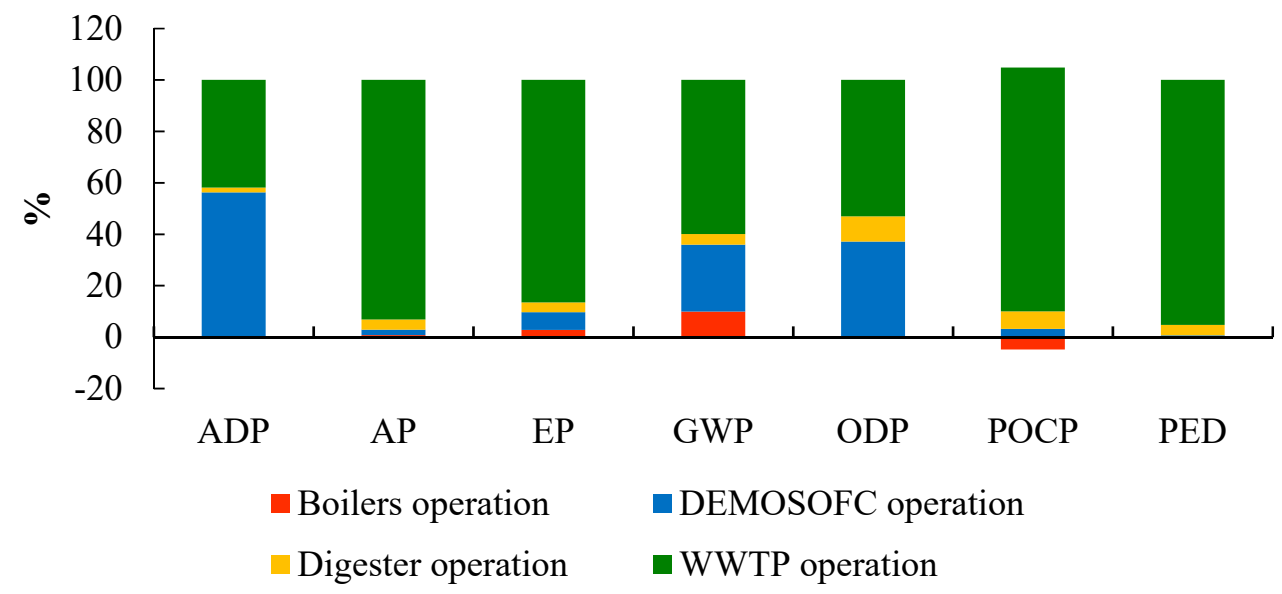

(c) Scenario 3

Figure 7. LCIA profile of the three scenarios (ADP: Abiotic Depletion Potential of elements, AP: Acidification Potential, EP : Eutrophication Potential, GWP: Global Warming Potential, ODP: Ozone Depletion Potential, PED: Primary Energy Demand, POCP: Photochemical Ozone Creation Potential). 


\subsection{Interpretation of Results and Comparison between the Assessed Scenarios}

The second step in the analysis of results is the cross-comparison of obtained LCIA profiles for the three scenarios. As shown in Figure 8, the impact of the second and third scenarios is lower than in the reference case in five of the seven impact categories analyzed. Processes involved in the analysis are grouped into five sections to better understand these outputs and facilitate the comparisons:

- Heat from the SOFC: Allocation based on exergy (8.1\% of the operational phase of the CHP system)

- Heat from boilers: Natural gas and biogas consumption and combustion's emissions

- $\quad$ Digester: Electricity and lubricating oil for its operation, flare and pipe leakage emissions

- Electricity from the SOFC: Allocation based on exergy (91.9\% of the operational phase of the CHP system)

- $\quad$ Electricity from the grid: Electricity required by the WWTP (excluded that auto-produced from SOFC)

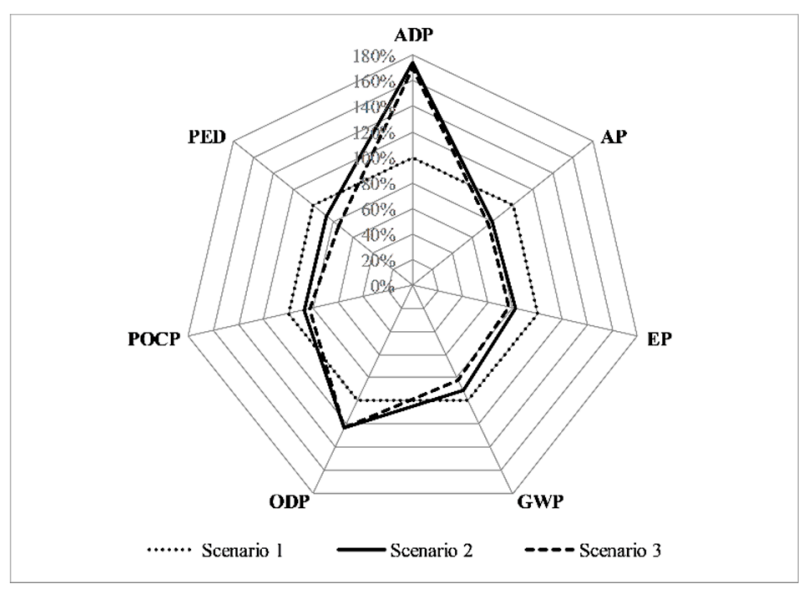

Figure 8. Impact assessment results.

The ADP of elements is higher in the WWTP with the cogeneration system installed. This fact is not unexpected since the manufacture and maintenance of many components is included in these scenarios. Looking at Figure 9a, the ADP of electricity produced from the SOFC modules is higher than that associated to electricity withdrawn from the grid since the total amount of electrical energy required in all the scenarios is almost the same (in the CHP systems a slight increase of consumed energy is owed to the balance of plant's absorptions). The ADP associated with heat from boilers in the third scenario is null thanks to the reached independence from natural gas.

The AP (Figure $9 \mathrm{~b}$ ) in the second and third scenarios is reduced by $20.6 \%$ and $24.2 \%$ respectively, compared to the reference. Electricity produced from the CHP units is significantly less impacting than that purchased from the grid. This is because during the life cycle phases of manufacture, maintenance and operation of the cogeneration system few emissions of substances with a high AP (e.g., $\mathrm{SO}_{2}$ and $\mathrm{NO}_{x}$ ) occur. Among the processes with a higher specific AP, there is the use of nickel, needed for EEA and catalyst manufacture. The AP of heat produced in boilers is strictly associated with the use of natural gas for its production.

A reduction of the EP (Figure 9c) by $17.7 \%$ compared to the reference case is obtained with the CHP system, and by $22.6 \%$ if also dynamic pre-thickening of sludge is performed. The self-produced electricity has a lower impact than that withdrawn from the grid. EP of thermal energy produced by boilers is primarily linked to nitrous oxide emissions associated with the combustion process. In fact, in the third scenario, in which a lower amount of heat is produced through combustion, the EP decreases. 


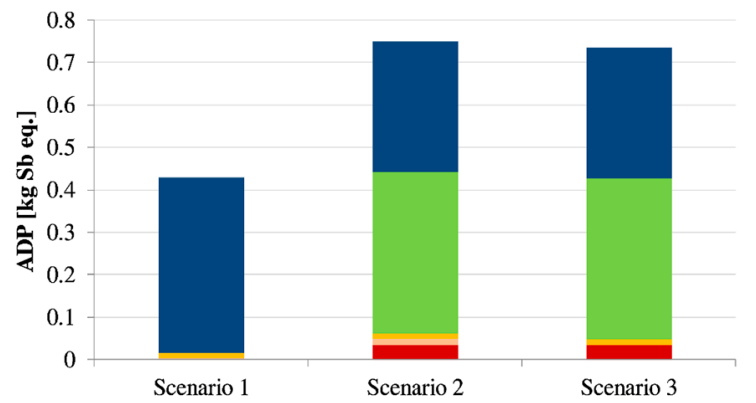

(a)

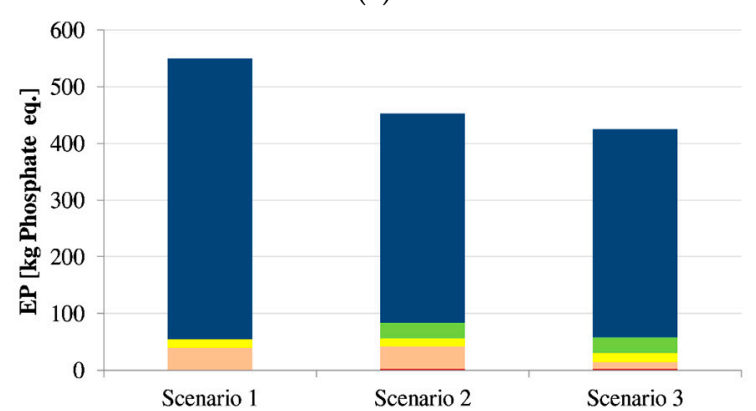

(c)

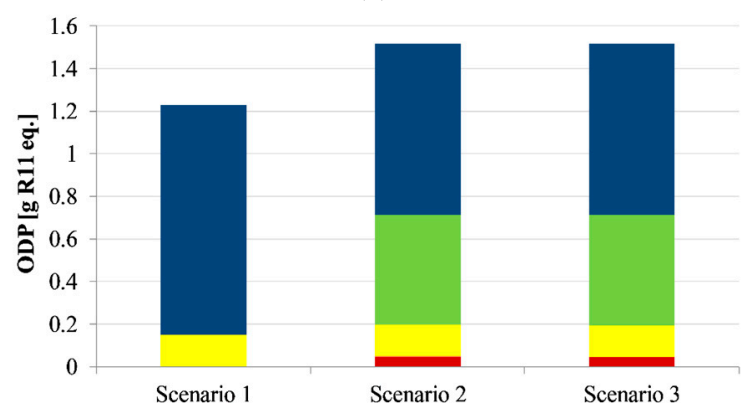

(e)

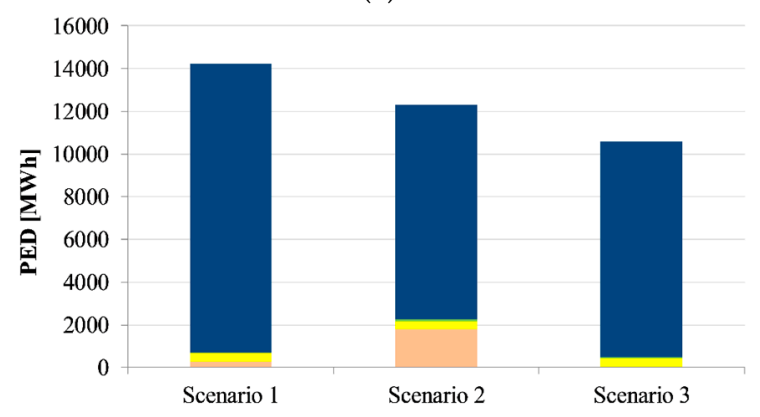

$(\mathrm{g})$

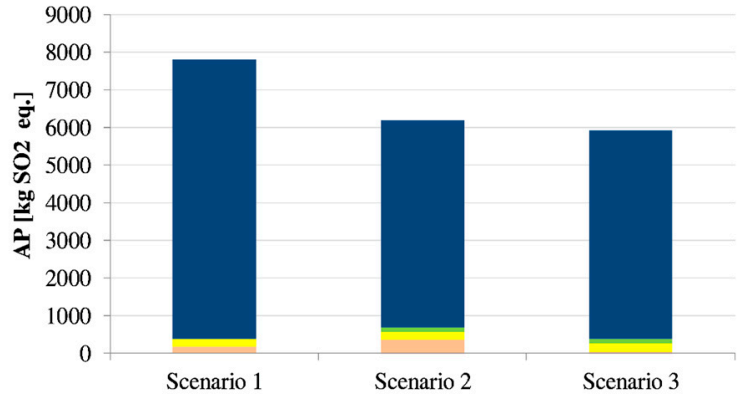

(b)

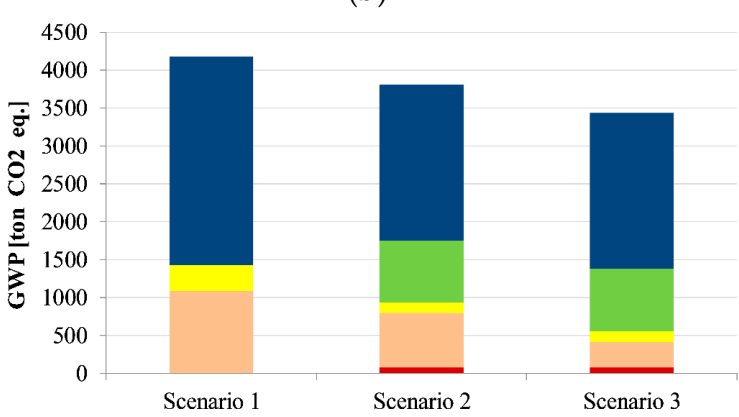

(d)

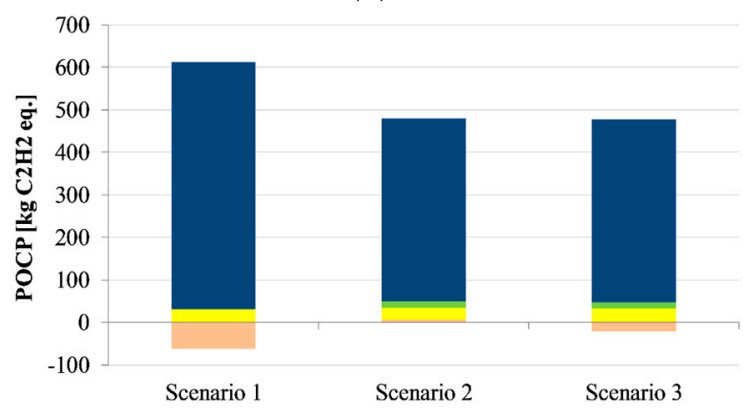

(f)

- Heat, SOFC $\quad$ Heat, boilers Digester

Electricity, SOFC $\square$ Electricity, grid

\section{Legend}

Figure 9. Impact categories result for the three analyzed scenarios. The following impact categories are shown: (a) ADP; (b) AP; (c) EP; (d) GWP; (e) ODP; (f) POCP and (g) PED.

GWP impact (Figure 9d) is reduced by $9 \%$ in the second scenario. This impact indicator is connected to the greenhouse gases emissions associated predominantly to operational phases of the life cycle. Therefore, advantages are associated to the primary energy savings measures adopted: better biogas management (only $0.2 \%$ is flared) and installation of the CHP system which avoids separate generation of a significant fraction of energy. The further thermal energy saving opportunity identified in the third scenario allows a reduction by $18 \%$ of GWP compared to the reference scenario.

The ODP (Figure 9e) of the two CHP scenarios increase by $23.6 \%$ compared to the reference WWTP. Here manufacture and maintenance phases play an important role; in particular nickel and 
LSM production give the highest specific contributions. As a result, the electricity produced from SOFC modules has a higher ODP than that from the Italian mix. The POCP (Figure 9f) is primarily linked to the operational phase of the WWTP.

Since the SOFC-based CHP system has negligible emissions of VOCs and $\mathrm{NO}_{\mathrm{x}}$, the electricity produced has a lower impact than that withdrawn from the grid. The negative contributions in the histogram are owed to the NO emissions from combustion in boilers (which promote tropospheric ozone decomposition in $\mathrm{NO}_{2}$ and $\mathrm{O}_{2}$ ). The emissions of substances which promote bad- $\mathrm{O}_{3}$ formation during the supply of natural gas (e.g., during extraction and transport processes) are annulled in the third scenario due to NG independence.

PED (Figure 9g) associated with the manufacture and maintenance of the CHP units is very low if compared to that needed during system operations. This is a quite common situation in life cycle assessments of energy systems. As a consequence, the contributions to PED associated with heat and electricity produced from SOFC modules are imperceptible in Figure 9g. The second and third scenarios allow a reduction by $13.5 \%$ and by $25.7 \%$ of PED respectively. In the third scenario, the decrease in PED associated with the annulment of natural gas consumption prevails over its increase during operations of the dynamic machine.

\subsection{Energy and Carbon Payback Times}

Energy and carbon payback times have been calculated dividing the embodied energy/ $\mathrm{CO}_{2}$ emissions in the manufacture and maintenance of the system by the net annual energy/ $\mathrm{CO}_{2}$ emissions savings due to the operation of the $\mathrm{CHP}$ units in the second and third scenario. Embodied energy/ $/ \mathrm{CO}_{2}$ emissions in the manufacture and maintenance of the system are $5002 \mathrm{GJ}$ and $227 \mathrm{tonCO}_{2}$ for the entire plant lifetime (20 years). Emissions savings due to the operation of the CHP units are, for Scenario 2, $7147 \mathrm{GJ} / \mathrm{y}$ and 421 tonCO $2 / y$; for Scenario 3, 13,405 GJ/y and 771 tonCO $2 / y$. Results are reported in Table 12, referred in this chapter to IT energy mix.

Table 12. PBT (Payback times) and sensitivity analysis on IT and EU energy mix.

\begin{tabular}{ccc}
\hline PBT [Years] & Scenario 2 & Scenario 3 \\
\hline Energy, IT mix & 0.70 & 0.37 \\
\hline Energy, EU mix & 0.63 & 0.36 \\
\hline Carbon, IT mix & 0.54 & 0.29 \\
\hline Carbon, EU mix & 0.56 & 0.31 \\
\hline
\end{tabular}

\subsection{Sensitivity Analysis}

In the last part of this study, a sensitivity analysis is performed, with the aim of determining the extent to which changes in the electricity consumption and the natural gas supply mix can affect results in terms of impact assessment (environmental impact and sustainability indicators). Attention is focused on these energetic flows since the analysis of the LCIA profiles of the different scenarios has stressed their essential contribution in all the impact categories. The Italian mix previously employed is substituted with the EU-27 mix to represent a general situation not affected by the peculiarities of a specific energetic portfolio. In Figure 10 the mixes relative to the year 2009 (last update available), used in the Ecoinvent database, are reported. Concerning the production of electricity in the Italian mix, higher penetration of renewable resources (even if a substantial share is associated with hydro) and larger use of natural gas can be observed. Instead, the EU-27 mix is characterized by a diffused use of coal and a significant nuclear production; together these sources represent more than half of electrical consumptions. In Italy natural gas is predominantly supplied by Algeria, Russia, Libya, and a significant share is also auto-produced (around 10\%) while in the EU-27 major contributions to the supply mix come from Netherlands, Russia, Norway and UK. 
Electricity: IT supply mix

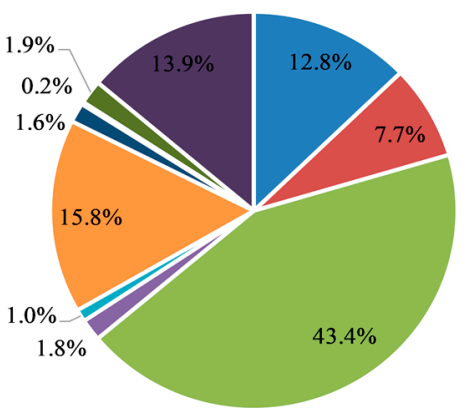

NG: IT supply mix

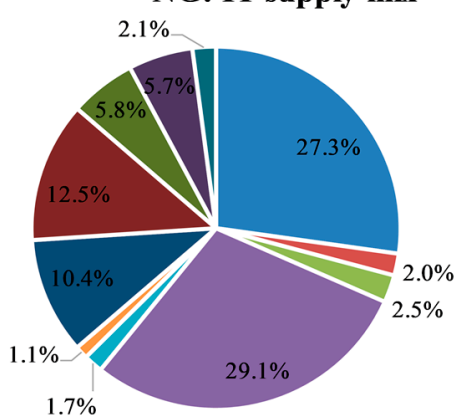

- coal

- oil

" gas

- biofuels

- waste

" hydro

- geothermal

- solar PV

" wind

- imports

- Russia

- Austria

- Germany

- Algeria

- Algeria LNG

- Croatia

- Italy

- Lybia

- Netherlands

- Norway

- Qatar LNG

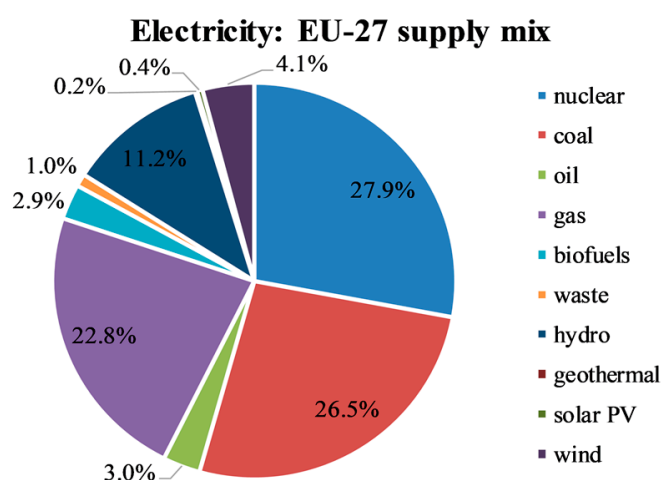

NG: EU-27 supply mix

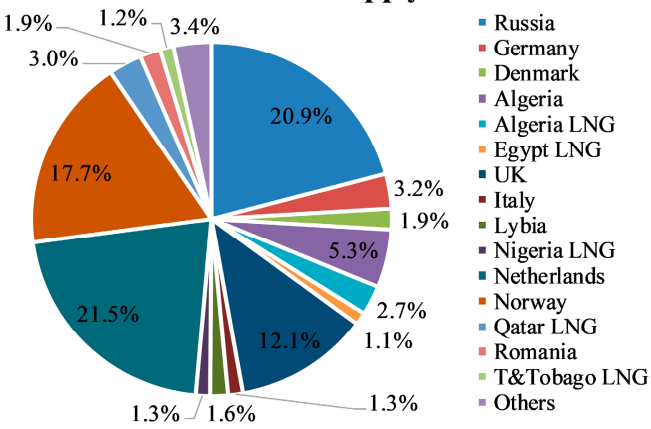

Figure 10. Energetic mixes used for the sensitivity analysis.

In Figure 11 the results of the impact assessment comparing EU-27 and Italian mixes for the second and third scenario are represented. Potential impacts obtained using Italian mixes are lower in five of the seven analyzed impact categories, and major advantages arise for ODP and AP. The WWTP in the third scenario does not need natural gas, so it is not sensitive to variation associated with this flow. Since the trend for both scenarios is comparable, it can be said that LCIA results are more sensitive to change in the electricity mix than in the natural gas mix. This fact is in agreement with the high electrical demand of the WWTP but also underlines the importance that the renewable nature of electricity has in a life cycle assessment.

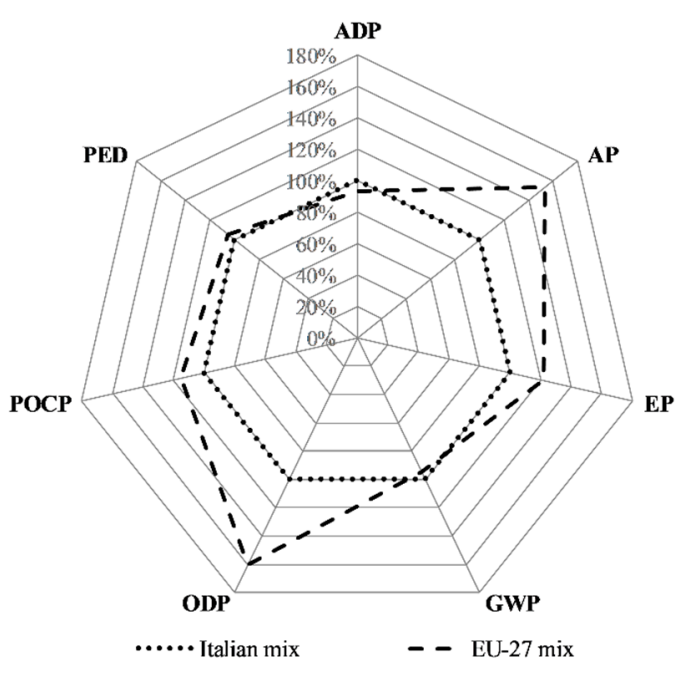

Scenario 2

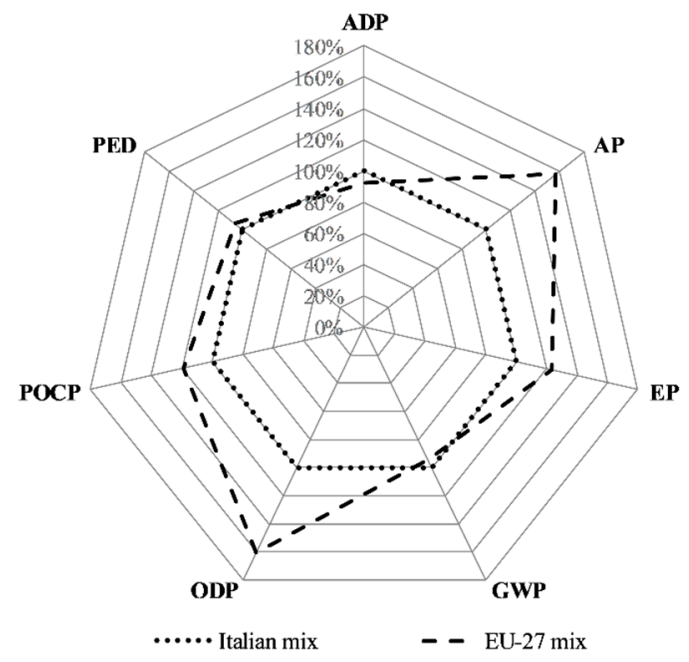

Scenario 3

Figure 11. Sensitivity analysis of the second and third scenario. 
Finally, in Figure 12 are reported results of the second and third scenarios concerning the reference one using the energetic mixes previously introduced. The trends are very similar except for the ODP category which becomes slightly smaller than in the first scenario if EU-27 mixes are used. Energy and carbon payback times are low sensitive to variation in energetic mixes (Table 12).

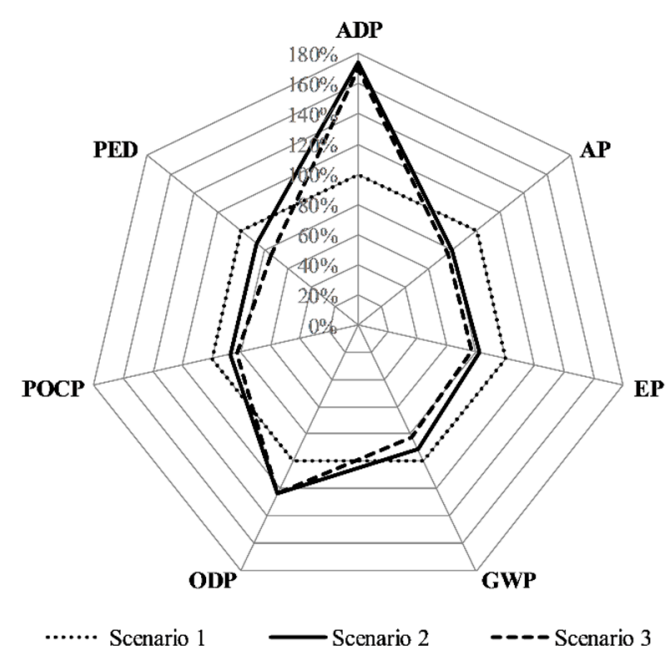

IT energy mix

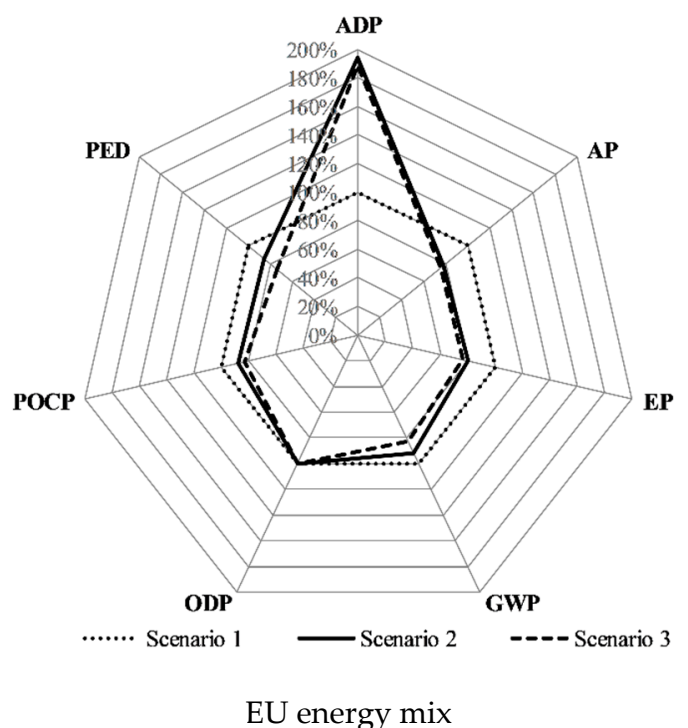

EU energy mix

Figure 12. Impact categories about the first scenario with EU-27 and Italian mix.

\section{Conclusions}

Three alternative scenarios for biogas exploitation in a medium-sized wastewater treatment plant have investigated in this work about their environmental performances. Real data from an integrated SOFC-WWTP have been retrieved from the DEMOSOFC project for what concerns the operation of the SOFC.

A large amount of electricity required for WWTP operations urges for a recovery of the produced biogas, which is available on-site and could cover much of such demand. By the life cycle assessment methodology, the potential reduction of the environmental burdens of a WWTP, in which efficient SOFC-based CHP modules are installed, is assessed. A thermal energy conservation opportunity that foresees the use of a dynamic machine for sludge pre-thickening enhancement is also investigated.

The operational phase of the analyzed components inside the WWTP has proven to be determinant in all the impact category analyzed. The depletion of non-renewable resources (ADP) is primarily linked to the manufacture and maintenance of the cogeneration units and the tailored balance of plant. In the first scenario, a predominant part of the impact in all the categories is associated with the electricity withdrawn from the grid. The LCIA has shown that producing a substantial share of electrical energy (around 25\%) via biogas-fed SOFC cogeneration modules can reduce the environmental burdens associated to WWTP operations in five out of the seven impact categories that have been analyzed in this work: AP, EP, GWP, POCP, and PED. A further reduction of impacts, particularly concerning GWP and PED, is possible by the decrease of the thermal demand of the digester, thus making the system independent from natural gas. In both Scenarios 2 and 3, primary energy and $\mathrm{CO}_{2}$ emissions embodied in the manufacture and maintenance of the CHP system are neutralized by operational savings in less than one year.

The sensitivity of LCIA outputs to a variation of electricity consumption and natural gas supply mixes is relevant mainly in the regional impact categories AP, EP and POCP, but also global ODP. The EU-27 mix has a higher impact than the Italian one because a larger dependence on more polluting fossil sources (coal is still employed in large quantities) and nuclear has been highlighted. It is worth to remember that data of energetic mixes available in the software are of 2009 and in the 
meanwhile significant changes occurred. Nevertheless, it can be said that the quality of produced electricity, measured in terms of its renewable origins, plays a decisive role in the life cycle assessment of energy-intensive systems. Positive effect on environmental loads of second and third scenarios are confirmed when the EU-27 mixes are used; furthermore, a slight reduction of ODP, compared to the first scenario, is obtained.

Main limits associated to this study are low availability of specific data concerning manufacturing and maintenance phases of the balance of plant that makes necessary the use of some rough assumptions, and the exclusion from the boundaries of the work of end of life scenarios (e.g., recycle or disposal of materials) due to lack of usable information. Anyway, the model could be further refined and improved for future studies.

Pursue of electrical and thermal self-sufficiency of WWTPs through the installation of efficient cogeneration systems, and the careful evaluation of energy conservation opportunities both in sludge and water lines seem to go in the right direction towards better environmental sustainability.

Author Contributions: Conceptualization, M.S., M.G., A.L., S.B. and G.A.B.; methodology, S.B., G.A.B. and M.G.; software, F.D.S. and S.B.; formal analysis, F.D.S.; investigation, F.D.S.; data curation, F.D.S. and M.G.; writing-original draft preparation, M.G. and F.D.S.; writing—review and editing, S.B., A.L., M.S., G.A.B. and M.G.; visualization, M.G.; supervision, M.S. and G.A.B.; funding acquisition, M.S.

Funding: This project has received funding from the Fuel Cells and Hydrogen 2 Joint Undertaking under grant agreement No 671470. This Joint Undertaking receives support from the European Union's Horizon 2020 research and innovation programme, Hydrogen Europe and Hydrogen Europe research.

Acknowledgments: The authors would like to thank Convion Oy and SMAT s.p.a. for supplying initial data on the SOFC modules and the Collegno wastewater treatment plant.

Conflicts of Interest: The authors declare no conflict of interest.

\section{Nomenclature}

$\begin{array}{ll}\text { ADP } & \text { Abiotic Depletion Potential of elements } \\ \text { AP } & \text { Acidification Potential } \\ \text { APU } & \text { Auxiliary Power Unit } \\ \text { CHP } & \text { Combined Heat and Power } \\ \text { EP } & \text { Eutrophication Potential } \\ \text { FC } & \text { Fuel Cell } \\ \text { GWP } & \text { Global Warming Potential } \\ \text { LCA } & \text { Life Cycle Assessment } \\ \text { LCI } & \text { Life Cycle Inventory } \\ \text { LCT } & \text { Life Cycle Thinking } \\ \text { ODP } & \text { Ozone Depletion Potential } \\ \text { PED } & \text { Primary Energy Demand } \\ \text { POCP } & \text { Photochemical Ozone Creation Potential } \\ \text { SOFC } & \text { Solid Oxide Fuel Cell } \\ \text { WWTP } & \text { Waste Water Treatment Plant }\end{array}$

\section{Appendix A}

Energy flows referred to the three analyzed scenarios are provided below. Input electricity to the anaerobic digester operation and WWTP operation are shown, together with heat input (both from biogas and NG). 


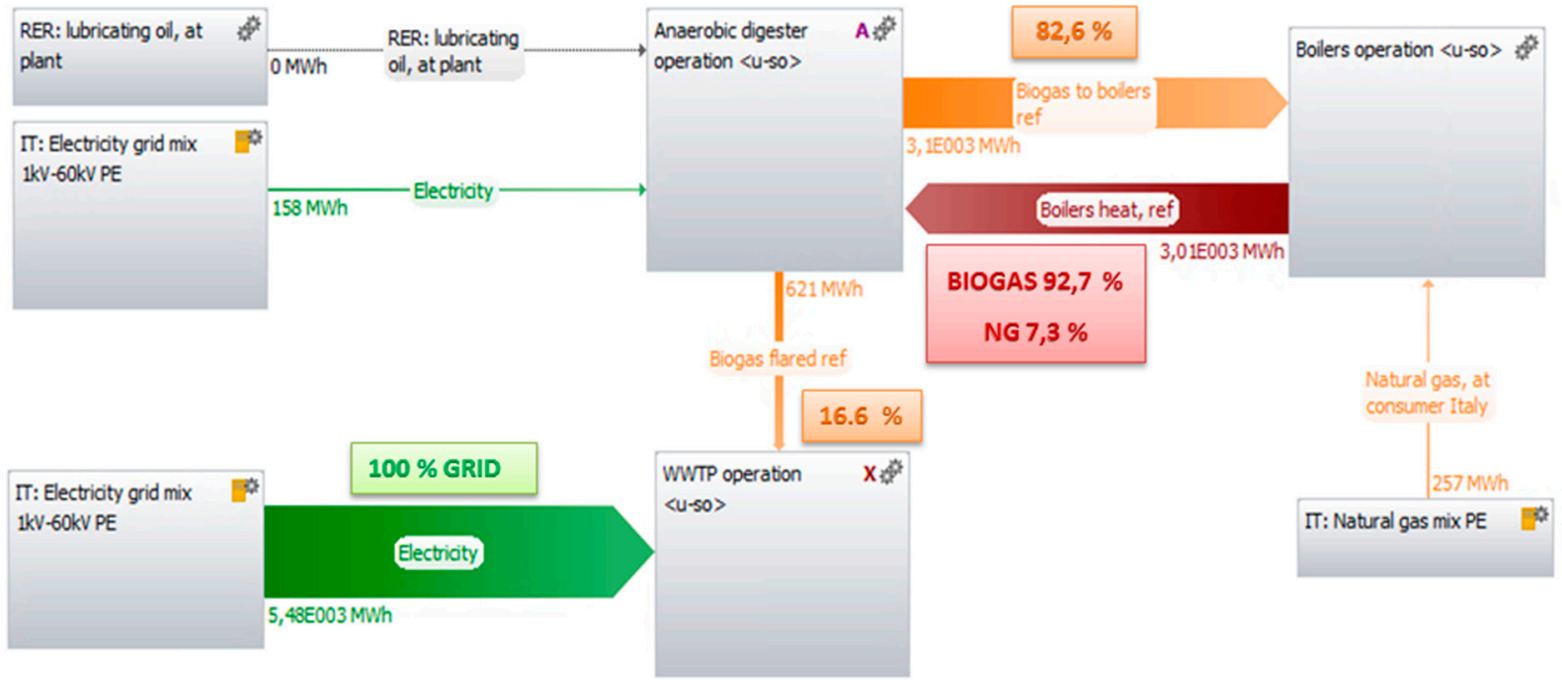

Figure A1. Energetic flows in Scenario 1.

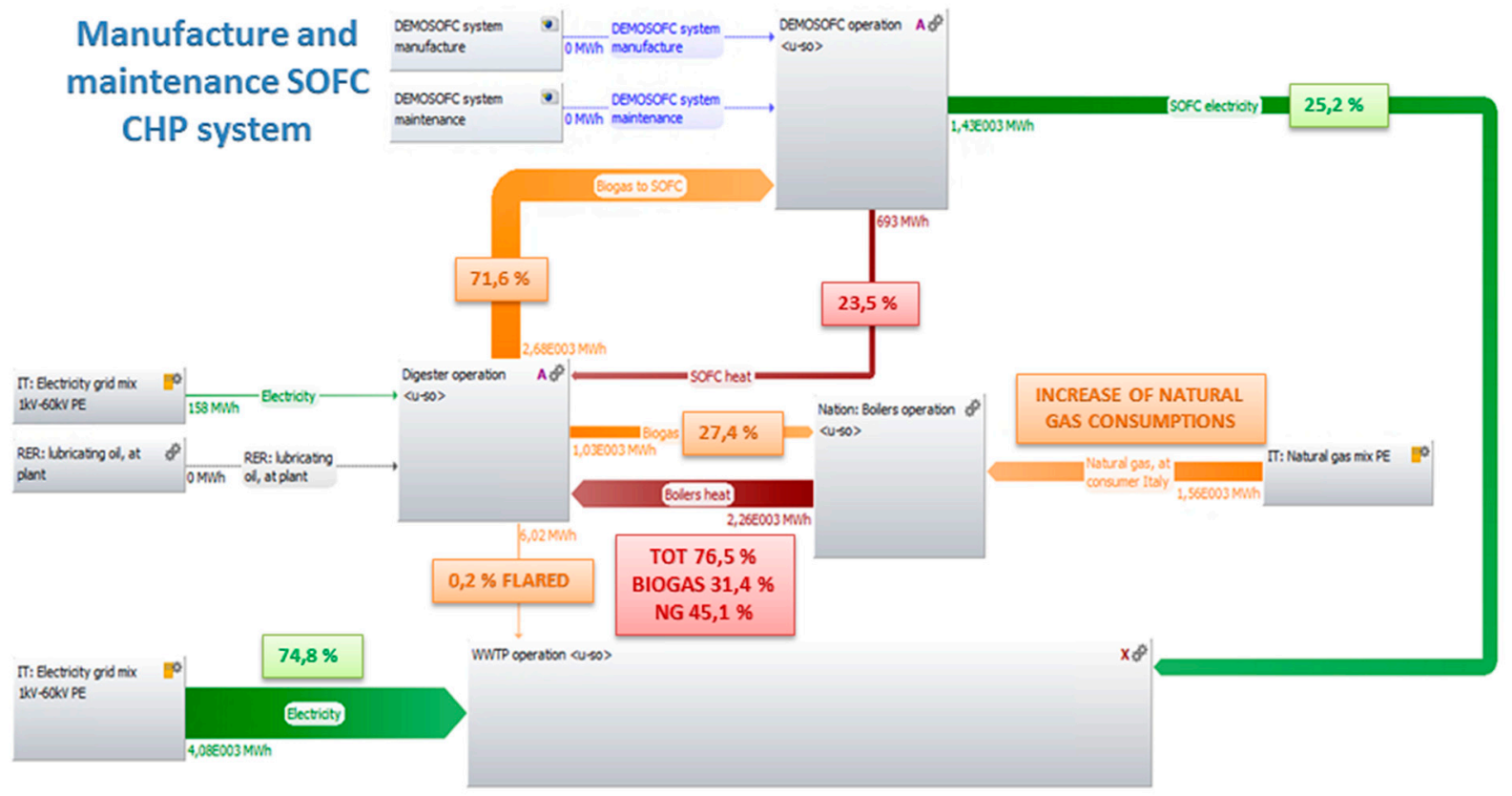

Figure A2. Energetic flows in Scenario 2. 


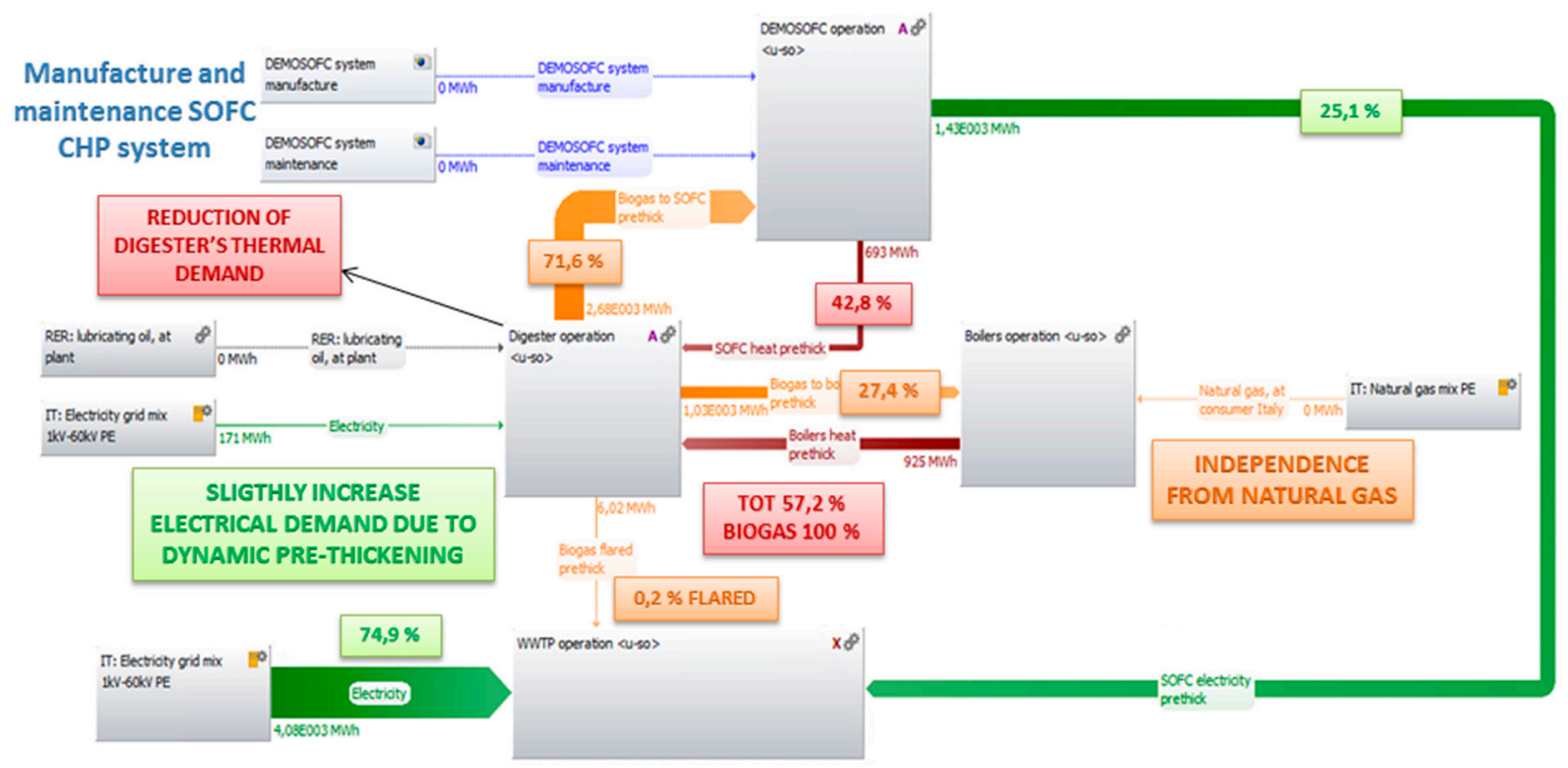

Figure A3. Energetic flows in Scenario 3.

\section{References}

1. Kitous, A.; Keramidas, K. Analysis of Scenarios Integrating the INDCs-JRC POLICY BRIEF; European Comission: Brussels, Belgium, 2015.

2. Adamson, K.-A. The Fuel Cell and Hydrogen Annual Review 2016; 4th Energy Wave: Edinburgh, Scotland, 2016.

3. Lewis, J. Stationary fuel cells-Insights into commercialisation. Int. J. Hydrogen Energy 2014, 39, $21896-21901$. [CrossRef]

4. Pirkandi, J.; Mahmoodi, M.; Ommian, M. An optimal configuration for a solid oxide fuel cell-gas turbine (SOFC-GT) hybrid system based on thermo-economic modelling. J. Clean. Prod. 2017, 144, 375-386. [CrossRef]

5. Santarelli, M.; Briesemeister, L.; Gandiglio, M.; Herrmann, S.; Kuczynski, P.; Kupecki, J.; Lanzini, A.; Llovelld, F.; Papurello, D.; Spliethoff, H.; et al. Carbon recovery and re-utilization (CRR) from the exhaust of a solid oxide fuel cell (SOFC): Analysis through a proof-of-concept. J. CO 2 Util. 2017, 18, 206-221. [CrossRef]

6. Sala, S.; Reale, F.; Cristobal-Garcia, J.; Pant, R. Life Cycle Assessment for the Impact Assessment of Policies; European Commission: Ispra, Italy, 2016; ISBN 9789279648137.

7. Dewulf, J.; De Meester, S.; Alvarenga, R. Sustainability Assessment of Renewables-Based Products: Methods and Case Studies; John Wiley \& Sons: Hoboken, NJ, USA, 2015; ISBN 9781118933947.

8. European Commission Circular Economy Strategy-Environment-European Commission. Available online: http://ec.europa.eu/environment/circular-economy/index_en.htm (accessed on 24 September 2018).

9. ISO. ISO 14040:2006-Environmental Management_Life Cycle Assessment_Principles and Framework; ISO: Geneva, Switzerland, 2016.

10. ISO. ISO 14044:2006-Environmental Management-Life Cycle Assessment-Requirements and Guidelines; ISO: Geneva, Switzerland, 2016.

11. European Commission-Joint Research Centre. Institute for Environment and Sustainability: International Reference Life Cycle Data System. In ILCD Handbook: General Guide for Life Cycle Assessment-Detailed Guidance; European Commission: Brussels, Belgium, 2010.

12. Jing, R.; Wang, M.; Wang, W.; Brandon, N.; Li, N.; Chen, J.; Zhao, Y. Economic and environmental multi-optimal design and dispatch of solid oxide fuel cell based CCHP system. Energy Convers. Manag. 2017, 154, 365-379. [CrossRef]

13. Benveniste, G.; Pucciarelli, M.; Torrell, M.; Kendall, M.; Tarancón, A. Life Cycle Assessment of microtubular solid oxide fuel cell based auxiliary power unit systems for recreational vehicles. J. Clean. Prod. 2017, 165, 312-322. [CrossRef] 
14. Zucaro, A.; Fiorentino, G.; Zamagni, A.; Bargigli, S.; Masoni, P.; Moreno, A.; Ulgiati, S. How can life cycle assessment foster environmentally sound fuel cell production and use? Int. J. Hydrogen Energy 2013, 38, 453-468. [CrossRef]

15. Masoni, P.; Zamagni, A. Guidance Document for Performing LCAs on Fuel Cells and $\mathrm{H}_{2}$ Technologies (Project FC-Hy Guide). Available online: http://www.fc-hyguide.eu/documents/10156/d0869ab9-4efe-4bea9e7a-1fb823f4fcfa (accessed on 7 March 2018).

16. Lunghi, P.; Bove, R.; Desideri, U. LCA of a molten carbonate fuel cell system. J. Power Sources 2004, 137, 239-247. [CrossRef]

17. Lunghi, P.; Bove, R.; Desideri, U. Life-cycle-assessment of fuel-cells-based landfill-gas energy conversion technologies. J. Power Sources 2004, 131, 120-126. [CrossRef]

18. Raugei, M.; Bargigli, S.; Ulgiati, S. A multi-criteria life cycle assessment of molten carbonate fuel cells (MCFC)-A comparison to natural gas turbines. Int. J. Hydrogen Energy 2005, 30, 123-130. [CrossRef]

19. Mehmeti, A.; Santoni, F.; Della, M.; Mcphail, S.J. Life cycle assessment of molten carbonate fuel cells: State of the art and strategies for the future. J. Power Sources 2016, 308, 97-108. [CrossRef]

20. Staffell, I.; Ingram, A.; Kendall, K. Energy and carbon payback times for solid oxide fuel cell based domestic CHP. Int. J. Hydrogen Energy 2012, 37, 2509-2523. [CrossRef]

21. Evangelisti, S.; Lettieri, P.; Borello, D.; Clift, R. Life cycle assessment of energy from waste via anaerobic digestion: A UK case study. Waste Manag. 2014, 34, 226-237. [CrossRef] [PubMed]

22. Evangelisti, S.; Tagliaferri, C.; Brett, D.J.L.; Lettieri, P. Life cycle assessment of a polymer electrolyte membrane fuel cell system for passenger vehicles. J. Clean. Prod. 2017, 142, 4339-4355. [CrossRef]

23. Duclos, L.; Lupsea, M.; Mandil, G.; Svecova, L.; Thivel, P.X.; Laforest, V. Environmental assessment of proton exchange membrane fuel cell platinum catalyst recycling. J. Clean. Prod. 2017, 142, 2618-2628. [CrossRef]

24. Kim, D.; Kim, J.; Koo, C.; Hong, T.; Kim, D.; Kim, J.; Koo, C.; Hong, T. An Economic and Environmental Assessment Model for Selecting the Optimal Implementation Strategy of Fuel Cell Systems-A Focus on Building Energy Policy. Energies 2014, 7, 5129-5150. [CrossRef]

25. Longo, S.; Cellura, M.; Guarino, F.; Ferraro, M.; Antonucci, V.; Squadrito, G. Life Cycle Assessment of Solid Oxide Fuel Cells and Polymer Electrolyte Membrane Fuel Cells. In Hydrogen Economy; Elsevier: Amsterdam, The Netherlands, 2017; pp. 139-169. ISBN 9780128111321.

26. Mehmeti, A.; Mcphail, S.J.; Pumiglia, D.; Carlini, M. Life cycle sustainability of solid oxide fuel cells: From methodological aspects to system implications. J. Power Sources 2016, 325, 772-785. [CrossRef]

27. Tonini, D.; Astrup, T. LCA of biomass-based energy systems: A case study for Denmark. Appl. Energy 2012, 99, 234-246. [CrossRef]

28. Sadhukhan, J. Distributed and micro-generation from biogas and agricultural application of sewage sludge: Comparative environmental performance analysis using life cycle approaches. Appl. Energy 2014, 122, 196-206. [CrossRef]

29. Aziz, N.I.H.A.; Hanafiah, M.M.; Gheewala, S.H. A review on life cycle assessment of biogas production: Challenges and future perspectives in Malaysia. Biomass Bioenergy 2019, 122, 361-374. [CrossRef]

30. Ayodele, T.R.; Ogunjuyigbe, A.S.O.; Alao, M.A. Economic and environmental assessment of electricity generation using biogas from organic fraction of municipal solid waste for the city of Ibadan, Nigeria. J. Clean. Prod. 2018, 203, 718-735. [CrossRef]

31. Garfí, M.; Castro, L.; Montero, N.; Escalante, H.; Ferrer, I. Evaluating environmental benefits of low-cost biogas digesters in small-scale farms in Colombia: A life cycle assessment. Bioresour. Technol. 2019, 274, 541-548. [CrossRef]

32. Gabisa, E.W.; Gheewala, S.H. Potential, environmental, and socio-economic assessment of biogas production in Ethiopia: The case of Amhara regional state. Biomass Bioenergy 2019, 122, 446-456. [CrossRef]

33. Ali, M.Y.; Hassan, M.; Rahman, M.A.; Kafy, A.-A.; Ara, I.; Javed, A.; Rahman, M.R. Life cycle energy and cost analysis of small scale biogas plant and solar PV system in rural areas of Bangladesh. Energy Procedia 2019, 160, 277-284. [CrossRef]

34. Esteves, E.M.M.; Herrera, A.M.N.; Esteves, V.P.P.; Morgado, C.D.R.V. Life cycle assessment of manure biogas production: A review. J. Clean. Prod. 2019, 219, 411-423. [CrossRef]

35. Ingrao, C.; Bacenetti, J.; Adamczyk, J.; Ferrante, V.; Messineo, A.; Huisingh, D. Investigating energy and environmental issues of agro-biogas derived energy systems: A comprehensive review of Life Cycle Assessments. Renew. Energy 2019, 136, 296-307. [CrossRef] 
36. Torquati, B.; Venanzi, S.; Ciani, A.; Diotallevi, F.; Tamburi, V.; Torquati, B.; Venanzi, S.; Ciani, A.; Diotallevi, F.; Tamburi, V. Environmental Sustainability and Economic Benefits of Dairy Farm Biogas Energy Production: A Case Study in Umbria. Sustainability 2014, 6, 6696-6713. [CrossRef]

37. Pehnt, M. Life-cycle assessment of fuel cell stacks. Int. J. Hydrogen Energy 2001, 26, 91-101. [CrossRef]

38. Nease, J.; Ii, T.A.A. Comparative life cycle analyses of bulk-scale coal-fueled solid oxide fuel cell power plants. Appl. Energy 2015, 150, 161-175. [CrossRef]

39. Bicer, Y.; Khalid, F. Life cycle environmental impact comparison of solid oxide fuel cells fueled by natural gas, hydrogen, ammonia and methanol for combined heat and power generation. Int. J. Hydrogen Energy 2018. (In press) [CrossRef]

40. Scataglini, R.; Mayyas, A.; Wei, M.; Chan, H.; Lipman, T.; Gosselin, D.; D’alessio, A.; Breunig, H.; Colella, W.G.; James, B.D.; et al. A Total Cost of Ownership Model for Solid Oxide Fuel Cells in Combined Heat and Power and Power-Only Applications; Lawrence Berkeley National Laboratory: Alameda County, CA, USA, 2015.

41. Convion Fuel Cell Systems Convion. Available online: http://convion.fi/ (accessed on 11 April 2019).

42. De Haas, D.; Dancey, M. Wastewater treatment energy efficiency-A review with current Australian perspectives. Water 2015, 53-58. [CrossRef]

43. Bachmann, N. Sustainable Biogas Production in Municipal Wastewater Treatment Plants-Technical Brochure of IEA Bioenergy. Available online: https://www.ieabioenergy.com/publications/sustainable-biogas-productionin-municipal-wastewater-treatment-plants/ (accessed on 1 December 2018).

44. Daw, J.; Hallett, K.; Dewolfe, J.; Venner, I. Energy Efficiency Strategies for Municipal Wastewater Treatment Facilities-Technical Report of NREL (National Renewable Energy Laboratory). Available online: https: //www.nrel.gov/docs/fy12osti/53341.pdf (accessed on 22 November 2016).

45. Panepinto, D.; Fiore, S.; Zappone, M.; Genon, G.; Meucci, L. Evaluation of the energy efficiency of a large wastewater treatment plant in Italy. Appl. Energy 2016, 161, 404-411. [CrossRef]

46. Ruffino, B.; Campo, G.; Genon, G.; Lorenzi, E.; Novarino, D.; Scibilia, G.; Zanetti, M. Improvement of anaerobic digestion of sewage sludge in a wastewater treatment plant by means of mechanical and thermal pre-treatments: Performance, energy and economical assessment. Bioresour. Technol. 2015, 175, $298-308$. [CrossRef]

47. Ruffino, B.; Campo, G.; Zanetti, M.C.; Genon, G. Improvement of the anaerobic digestion of activated sludge: Thermal and economical perspectives. WIT Trans. Ecol. Environ. 2014, 190, 979-991.

48. The New York State Energy Research and Development Authority. Water \& Wastewater Energy Management Best Practices Handbook; The New York State Energy Research and Development Authority: Albany, NY, USA, 2010.

49. SMAT Società Metropolitana Acque Torino S.p.A. Available online: http://www.smatorino.it/ (accessed on 12 April 2019).

50. DEMOSOFC Project Official Website. Available online: www.demosofc.eu (accessed on 20 December 2015).

51. Giarola, S.; Forte, O.; Lanzini, A.; Gandiglio, M.; Santarelli, M.; Hawkes, A. Techno-economic assessment of biogas-fed solid oxide fuel cell combined heat and power system at industrial scale. Appl. Energy 2018, 211, 689-704. [CrossRef]

52. Mehr, A.S.; Gandiglio, M.; MosayebNezhad, M.; Lanzini, A.; Mahmoudi, S.M.; Yari, M.; Santarelli, M. Solar-assisted integrated biogas solid oxide fuel cell (SOFC) installation in wastewater treatment plant: Energy and economic analysis. Appl. Energy 2017, 191, 620-638. [CrossRef]

53. European Platform on Life Cycle Assessment (EPLCA) LCT-Our Thinking-Life Cycle Thinking. Available online: http://eplca.jrc.ec.europa.eu/?page_id=14 (accessed on 25 September 2018).

54. Stranddorf, H.K.; Hoffmann, L.; Schmidt, A. FORCE Technology Impact categories, normalisation and weighting in LCA. Environ. News 2005, 78, 90.

55. Gandiglio, M.; Lanzini, A.; Soto, A.; Leone, P.; Santarelli, M. Enhancing the energy efficiency of wastewater treatment plants through co-digestion and fuel cell systems. Front. Environ. Sci. 2017, 5, 70. [CrossRef]

56. Rillo, E.; Gandiglio, M.; Lanzini, A.; Bobba, S.; Santarelli, M.; Blengini, G. Life Cycle Assessment (LCA) of biogas-fed Solid Oxide Fuel Cell (SOFC) plant. Energy 2017, 126, 585-602. [CrossRef]

57. Scataglini, R.; Wei, M.; Mayyas, A.; Chan, S.H.; Lipman, T.; Santarelli, M. A Direct Manufacturing Cost Model for Solid-Oxide Fuel Cell Stacks. Fuel Cells 2017, 17, 825-842. [CrossRef]

58. Primas, A. Life Cycle Inventories of New CHP Systems; Ecoinvent Report No. 20; Ecoinvent Centre: Dübendorf, Switzerland, 2007. 
59. Farnell, P. Engineering Aspects of Hydrocarbon Steam Reforming Catalysts. Top. Catal. 2016, 59, $802-808$. [CrossRef]

60. Spath, P.L.; Mann, M.K. Life Cycle Assessment of Hydrogen Production Via Natural Gas Steam Reforming; National Renewable Energy Laboratory: Golden, CO, USA, 2001.

61. PIECE. Program for North American Mobility In Higher Education. In MODULE 14. "Life Cycle Assessment (LCA)" 4 Steps of LCA, Approaches, Software, Databases, Subjectivity, Sensitivity Analysis, Application to a Subjectivity, Sensitivity Analysis, Application to a Classic Example; 2017; Available online: https://vdocuments.mx/module-14life-cycle-assessment-lca-4-steps-of-lca-life-cycle-assessment.html (accessed on 24 April 2019).

62. Papadias, D.D.; Ahmed, S.; Kumar, R. Fuel quality issues with biogas energy-An economic analysis for a stationary fuel cell system. Energy 2012, 44, 257-277. [CrossRef]

63. Santarelli, M.; Lanzini, A.; Gandiglio, M.; Le Pera, A.; Lorenzi, E.; Hakala, T.; Hawkes, A. Energy Planning of the DEMOSOFC (Deliverable of the DEMOSOFC EU Project). Available online: http://www.demosofc.eu/ ?attachment_id=862 (accessed on 12 April 2019).

64. Santarelli, M.; Lanzini, A.; Gandiglio, M.; Papurello, D.; Lorenzi, E.; Hakala, T.; Hawkes, A. Optimization of the DEMOSOFC (Deliverable of the DEMOSOFC EU Project). Available online: http://www.demosofc.eu/ ?attachment_id=865 (accessed on 12 April 2019).

65. Santarelli, M.; Lanzini, A.; Gandiglio, M.; Papurello, D.; Vaudano, G.; Fausone, U.; Hakala, T.; Liukkonen, M. Detailed Engineering of the DEMOSOFC (Deliverable of the DEMOSOFC EU Project). Available online: https://drive.google.com/file/d/0Bxqph4W5H-_Uc1FnUzV4UUFKTTQ/view (accessed on 12 April 2019).

66. Jungbluth, N.; Dinkel, F.; Stettler, C.; Doka, G.; Chudacoff, M.; Dauriat, A.; Spielmann, M.; Sutter, J.; Emmenegger, M.F.; Gnansonou, E.; et al. Life Cycle Inventories of Bioenergy; Ecoinvent Report No. 17; Swiss Center Für Life Cycle Inventories: Dubendorf, Switzerland, 2007.

(C) 2019 by the authors. Licensee MDPI, Basel, Switzerland. This article is an open access article distributed under the terms and conditions of the Creative Commons Attribution (CC BY) license (http://creativecommons.org/licenses/by/4.0/). 